\title{
Analysis of Carotenoids in Haloarchaea Species from Atacama Saline Lakes by High Resolution UHPLC-Q-Orbitrap-Mass Spectrometry: Antioxidant Potential and Biological Effect on Cell Viability
}

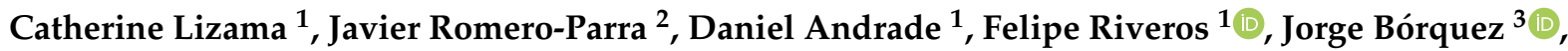 \\ Shakeel Ahmed ${ }^{4}\left[\right.$, Luis Venegas-Salas ${ }^{5}$, Carolina Cabalín ${ }^{5}$ and Mario J. Simirgiotis ${ }^{4, *}$ (D)
}

check for updates

Citation: Lizama, C.; Romero-Parra, J.; Andrade, D.; Riveros, F.; Bórquez, J.; Ahmed, S.; Venegas-Salas, L.; Cabalín, C.; Simirgiotis, M.J.. Analysis of Carotenoids in Haloarchaea Species from Atacama Saline Lakes by High Resolution UHPLC-Q-Orbitrap-Mass Spectrometry: Antioxidant Potential and Biological Effect on Cell Viability. Antioxidants 2021, 10, 1230. https:// doi.org/10.3390/antiox10081230

Academic Editors: Danila Limauro and Emilia Pedone

Received: 6 July 2021

Accepted: 27 July 2021

Published: 30 July 2021

Publisher's Note: MDPI stays neutral with regard to jurisdictional claims in published maps and institutional affiliations.

Copyright: (c) 2021 by the authors. Licensee MDPI, Basel, Switzerland. This article is an open access article distributed under the terms and conditions of the Creative Commons Attribution (CC BY) license (https:/ / creativecommons.org/licenses/by/ $4.0 /)$.
1 Departamento de Tecnología Médica, Facultad de Ciencias de la Salud, Universidad de Antofagasta, Antofagasta 1240000, Chile; catherine.lizama@uantof.cl (C.L.); daniel.andrade@uantof.cl (D.A.); felipe.riveros.c@hotmail.com (F.R.)

2 Departamento de Química Orgánica y Fisicoquímica, Facultad de Ciencias Químicas y Farmacéuticas, Universidad de Chile, Olivos 1007, Casilla 233, Santiago 6640022, Chile; javier.romero@ciq.uchile.cl

3 Departamento de Química, Facultad de Ciencias Básicas, Universidad de Antofagasta, Antofagasta 1240000, Chile; jorge.borquez@uantof.cl

4 Facultad de Ciencias, Instituto de Farmacia, Universidad Austral de Chile, Valdivia 5090000, Chile; shakeel.ahmed@uach.cl

5 Departamento de Enfermedades Infecciosas e Inmunología Pediátrica, Escuela de Medicina, Pontificia Universidad Católica de Chile, Santiago 8320000, Chile; luvenegas@uc.cl (L.V.-S.); crarenas@uc.cl (C.C.)

* Correspondence: mario.simirgiotis@uach.cl; Tel.: +56-999-835-427

\begin{abstract}
Haloarchaea are extreme halophilic microorganisms belonging to the domain Archaea, phylum Euryarchaeota, and are producers of interesting antioxidant carotenoid compounds. In this study, four new strains of Haloarcula sp., isolated from saline lakes of the Atacama Desert, are reported and studied by high-resolution mass spectrometry (UHPLC-Q-Orbitrap-MS/MS) for the first time. In addition, determination of the carotenoid pigment profile from the new strains of Haloarcula sp., plus two strains of Halorubrum tebenquichense, and their antioxidant activity by means of several methods is reported. The effect of biomass on cellular viability in skin cell lines was also evaluated by MTT assay. The cholinesterase inhibition capacity of six haloarchaea (Haloarcula sp. ALT-23; Haloarcula sp. TeSe-41; Haloarcula sp. TeSe-51; Haloarcula sp. Te Se-89 and Halorubrum tebenquichense strains TeSe-85 and Te Se-86) is also reported for the first time. AChE inhibition $\mathrm{IC}_{50}$ was $2.96 \pm 0.08 \mu \mathrm{g} / \mathrm{mL}$ and BuChE inhibition $\mathrm{IC}_{50}$ was $2.39 \pm 0.09 \mu \mathrm{g} / \mathrm{mL}$ for the most active strain, Halorubrum tebenquichense Te Se-85, respectively, which is more active in $\mathrm{BuCHe}$ than that of the standard galantamine. Docking calculation showed that carotenoids can exert their inhibitory activity fitting into the enzyme pocket by their halves, in the presence of cholinesterase dimers.
\end{abstract}

Keywords: UHPLC; Orbitrap; high resolution MS analysis; haloarchaea; bacterioruberin; carotenoids; cell viability in $\mathrm{HaCaT}$; Atacama saline lake; docking studies

\section{Introduction}

Haloarchaea are extreme halophilic microorganisms belonging to the domain Archaea, phylum Euryarchaeota. They are (mostly) aerobic, generally red pigmented and constitute the predominant microbial communities in extreme halophilic environments. The haloarchaea require at least $1.5 \mathrm{M} \mathrm{NaCl}$, but most strains grow best at 3.5-4.5 M NaCl, and have been isolated from different habitats including alkaline and salt lakes, marine salterns, The Dead Sea and saline soils [1]. The Atacama Saltern is an extreme environment in the east part of the Antofagasta district of Chile and it is situated at $2300 \mathrm{~m}$ above sea level, at $20^{\circ} 30^{\prime} \mathrm{S}$ and $68^{\circ} 15^{\prime} \mathrm{W}$. This environment has special extreme conditions that can distinguish it from other hypersaline environments. These features can be described 
as high salinity, high radiation (U.V), drastic changes in temperatures and high dryness. The Tebenquiche Lake is a practically anoxic [1] and hypersaline lake with neutral $\mathrm{pH}$ located in this region. The ionic composition of waters from this lake is dominated by sodium and chloride ions, but also with a high sulphate concentration in which the ionic dominance is $\mathrm{Na}>\mathrm{K}>\mathrm{Mg}>\mathrm{Ca}=\mathrm{Cl}>\mathrm{SO}_{4}>\mathrm{HCO}_{3}+\mathrm{CO}_{3}$ [2]. The haloarchaea strains isolated from this special lake are a source of unexplored bioactive carotenoid compounds that protect the strains from the poly-extreme conditions of this environment. Carotenoids have been studied with great interest due to their biotechnological applications and, more importantly, their possible beneficial effects on human health $[3,4]$. These compounds are the second most abundant natural pigments in nature [5] and are mainly C-40 lipophilic isoprenoids ranging from colorless to yellow, orange and red [6]. The production of such types of pigments has been described from plants and some microorganisms such as algae, cyanobacteria, yeasts [7], and fungi [8]. Haloarchaea can produce carotenoids according to culture conditions, but their main reported carotenoids are composed of 50 carbon atoms. These large carotenoids are cell membrane reinforcements and protect the microorganisms against DNA damaging agents, such as salinity and solar radiation [9]. However, carotenes from halophilic archaea did not receive considerable attention [9], even though they are a main product of Atacama Desert halophilic archaea, with the 50-carbon carotenoid $\alpha-$ bacterioruberin being reported as their main compound [6,10-14]. Various studies with haloarchaea carotenoid extracts have shown potential applications in biomedicine, such as: a decrease in cell viability in human hepatoma HepG2 cells [15]; beneficial effects on the viability of sperm cells [16]; antimicrobial activity [17]; in vitro antioxidant and antihemolytic activity [18] and anticancer and antiviral activity [19]. The objective of this study is the determination of the carotenoid pigment profile of isolated haloarchaea from Tebenquiche Lake of the Atacama Desert, namely two strains of Halorubrum tebenquichense and four new strains of Haloarcula sp., isolated from this saline lake that have not been previously studied for this purpose, through high resolution mass spectrometry (UHPLC-Q-Orbitrap-MS/MS). Additionally, the total carotenoid and phenolic content is determined, and the antioxidant capacity of the carotenoid-enriched extracts verified by DPPH, FRAP and ABTS colorimetric tests. Moreover, in vitro cholinesterase tests with the extracts of the new strains were performed, plus the geometries and partial charges of every identified carotenoid optimized using semi-empirical methods and docking experiments were performed in catalytic sites of acetylcholinesterase and human butyrylcholinesterase enzymes for the first time. Cellular viability by MTT assay and the effects of the haloarchaea extract in the skin cell line $\mathrm{HaCaT}$ were also examined.

\section{Materials and Methods}

\subsection{Chemicals}

Ultrapure water was obtained from a water purification system brand Millipore (Milli-Q Merck Millipore, Santiago, Chile). Analytical reagents were all purchased from Sigma Aldrich Co. (Santiago, Chile). Methanol, formic acid, acetone, and acetonitrile were of chromatographic grade for HPLC analysis. Folin-Ciocalteu reagent, agarose, trolox, astaxanthin $97 \%$ by $\mathrm{HPLC}, \mathrm{NaOH}, \mathrm{Na}_{2} \mathrm{CO}_{3}, \mathrm{AlCl}, \mathrm{FeCl}_{3}, \mathrm{HCl}, \mathrm{NaNO}_{2}$, astaxanthin $(95 \%$ purity by HPLC), trichloroacetic acid, quercetin, 6-hydroxy-2,5,7,8-tetramethylchromane-2carboxylic acid (Trolox), sodium acetate, TPTZ, nitroblue tetrazolium, DPPH (1,1-diphenyl2-picrylhydrazyl radical), ethanol, proteose peptone, and sodium carbonate $\left(\mathrm{Na}_{2} \mathrm{CO}_{3}\right)$ were of analytical reagent purity and were acquired from Sigma-Aldrich Chemical Company (Santiago, Chile).

\subsection{Strain and Cultivation Conditions}

The haloarchaea strains were isolated from Tebenquiche Lake of the Atacama Saltern and belong to the collection of extreme halophilic archaea of the Laboratory of Clinical and Environmental Microbiology of the Department of Medical Technology of the University of Antofagasta. They were cultivated in medium MH containing (per litre): $5 \mathrm{~g}$ proteose- 
peptone no. 5 (Difco, Thermo Fisher, Santiago, Chile), 10 g yeast extract (Difco, Thermo Fisher, Santiago, Chile), $1 \mathrm{~g}$ glucose with $25 \%(w / v)$ total salts. The stock of total salts at $30 \%(w / v)$ was prepared as described by Subov (1931). Liquid cultures were grown in Erlenmeyer flasks containing $200 \mathrm{~mL}$ of the liquid medium and cultured to a stationary phase for 10 days with and continuous agitation at $120 \mathrm{rpm}$ and $40{ }^{\circ} \mathrm{C}$. The biomass of the haloarchaea strains was obtained by centrifugation at 10,000 rpm for $15 \mathrm{~min}$, washed with a basal salt solution $20 \%(w / v) \mathrm{NaCl}$, and stored at $-80{ }^{\circ} \mathrm{C}$ until used.

\subsection{DNA Extraction and Amplification of $16 S$ rRNA Encoding Gene}

A $1.5 \mathrm{~mL}$ sample of culture the haloarchaea was harvested by centrifugation at $13,000 \times g$ for $5 \mathrm{~min}$ and $4{ }^{\circ} \mathrm{C}$. The resulting pellet was resuspended with $1 \mathrm{~mL}$ distilled water. The mixture was vortexed during $1 \mathrm{~min}$., and it was incubated for $60 \mathrm{~min}$ at $37^{\circ} \mathrm{C}$ until the extract acquired a viscous texture. Then, the procedure was performed as described in [20]. PCR amplification was carried out in $50 \mu \mathrm{L}$ volumes containing $2 \mathrm{mM}$ of $\mathrm{MgCl}_{2}$, 2U of GoTaq G2 Flexi DNA polymerase (Promega), $150 \mathrm{mM}$ of each dNTP, $0.5 \mathrm{mM}$ of the primer and $2 \mathrm{~mL}$ of template DNA. The primers ARCH21F: TTC CGG TTG ATC CTG CCG GA [21] and 1492R: TAC GGY TAC CTT GTT ACG [22] were used for amplification of the $16 \mathrm{~S}$ rRNA gene. The PCR program used was an initial denaturation $\left(80^{\circ} \mathrm{C}\right.$ for $\left.5 \mathrm{~min}\right), 32$ cycles of denaturation $\left(95^{\circ} \mathrm{C}\right.$ for $\left.1 \mathrm{~min}\right)$, annealing $\left(55^{\circ} \mathrm{C}\right.$ for $\left.1 \mathrm{~min}\right)$ and extension $\left(72{ }^{\circ} \mathrm{C}\right.$ for $\left.2 \mathrm{~min}\right)$, and a final extension $\left(72{ }^{\circ} \mathrm{C}\right.$ for $\left.10 \mathrm{~min}\right)$. PCR products were visualized on a $1 \%$ agarose gel with SAFEVIEW PLUS $(0.5 \mathrm{uL} / 100 \mathrm{~mL})$. Sequencing was performed directly on PCR products with the universal archaeal primer sets ARCH 21F and 1492R [21,22] and Arch 344F and 915R [23] using the Macrogen sequencing service (Macrogen Inc., Gangseo-gu, Seoul, Korea).

\subsection{Phylogenetics Analysis}

Closest relatives of the $16 \mathrm{~S}$ rDNA sequences were determined by BLAST search (http: / / www.ncbi.nlm.nih.gov/blast accessed on 27 July 2021) and the classifier tool in RDP II (http: / / www.cme.msu.edu/rdp; accessed on 27 July 2021). Pairwise similarities between sequences were determined using p-distance in MEGA X. Trees were edited using MEGA X [24]. The sequences were deposited in GenBank for accessions for the 16S rRNA gene sequences (Supplementary Materials).

\subsection{Preparation of the Sample for Analyses}

The biomass of the haloarchaea strains was obtained by centrifugation and stored at $-80{ }^{\circ} \mathrm{C}$ for two days. Then, the samples were lyophilized in a freeze-evaporation system (Model 7670541 FreeZone 2.5 Liter Labconco Freeze Dry Systems, Palo Alto, CA, USA) where all water contained in the original product was removed by freeze-evaporation cycles. The lyophilizate was stored in $15 \mathrm{~mL}$ Falcon centrifuge tubes protected from light, and once the dry weight was determined, it was stored at $-20^{\circ} \mathrm{C}$ until use. The lyophilized material (0.3-1.0 g) was added $2 \mathrm{~mL}$ of an acetone: water mixture in a proportion (8: $2 v / v),[25]$, vortexed for $10 \mathrm{~min}$, then sonicated for $10 \mathrm{~min}$ and subsequently centrifuged at $4500 \mathrm{rpm}$ for $15 \mathrm{~min}$ at $-4{ }^{\circ} \mathrm{C}$. Three cycles of vortexing, ultra-sounding and centrifugation were employed until a final volume of $5 \mathrm{~mL}$ of supernatant was recovered, which was then stored at $-20^{\circ} \mathrm{C}$ protected from light until use.

\subsection{Determination of Total Phenols Content}

The determination of the total phenol content (TPC) was performed by the colorimetric method of Folin-Ciocalteu with some modifications [26,27]. To $100 \mu \mathrm{L}$ of the strain extract to be measured (at $2 \mathrm{mg} / \mathrm{mL}$ ), $940 \mu \mathrm{L}$ of Milli-Q water and $480 \mu \mathrm{L}$ of the $10 \%$ FolinCiocalteu reagent (Merck, Santiago, Chile) were added in a test tube, mixed using a vortex mixer. The prepared tube was allowed to react for $5 \mathrm{~min}$, and then $480 \mu \mathrm{L}$ of $10 \%$ sodium carbonate was added. The mixture was incubated at room temperature for $30 \mathrm{~min}$ in darkness. Absorbance was then measured at $765 \mathrm{~nm}$ using a UV-visible spectrophotometer 
(Spectroquant Pharo 300 Merck, Santiago Chile), using as blank Milli-Q water. The obtained absorbance values were replaced in the equation of the standard curve of Trolox (curve from 10-250 $\mu \mathrm{g} / \mathrm{mL}$ ). The content of phenolic compounds was expressed as Trolox micromoles per gram of extract ( $\mu$ mol Trolox/g extract).

\subsection{Determination of Total Carotenoids}

The determination of the total carotenoid content (TCC) was performed according to the spectroscopy methodologies usually employed [28,29] in visible spectroscopy [30]; briefly, $90 \mu \mathrm{L}$ of the strain extract (redissolved in acetone: water 8: 2; $v / v$ at a concentration: $2 \mathrm{mg} / \mathrm{mL}$ ) was added to $810 \mu \mathrm{L}$ of the same solvent mixture and its absorbance measured at $490 \mathrm{~nm}$ using a $1 \mathrm{~cm}$ wide quartz cuvette at $25^{\circ} \mathrm{C}$ in a UV-Vis spectrophotometer (Genesys 180, Thermo Fisher Scientific, San Jose, CA, USA). The total carotenoids were calculated as bacterioruberin content using its extinction coefficient $(\varepsilon 490)=2600 \mathrm{~L} \cdot \mathrm{mol}^{-1} \cdot \mathrm{cm}^{-1}[16]$, with the following formula:

$$
\text { Carotenoids content } \mu \mathrm{g} \cdot \mathrm{g}^{-1}=\frac{A \times V(m L) \times 10^{4}}{\varepsilon 490 \times P(g)}
$$

where $\mathrm{A}=$ absorbance; $\mathrm{V}=$ total extract volume; and $\mathrm{P}=$ sample weight; $\varepsilon 490=2600$ (Bacterioruberin extinction coefficient in acetone)

The results are expressed as micrograms per $g$ of the extract.

\subsection{Antioxidant Tests}

2.8.1. 1,1-Diphenyl-2-Picrylhydrazyl Radical Free Radical Scavenging Activity

The DPPH method previously reported by $[31,32]$ was used to evaluate the antioxidant activity of haloarchaea strains. Briefly, $150 \mu \mathrm{L}$ of a prepared solution of $400 \mu \mathrm{M} \mathrm{DPPH}$ solution was mixed with $50 \mu \mathrm{L}$ of standards or extracts, (curve from 10-250 $\mu \mathrm{g} / \mathrm{mL}$ ). The mixture was homogenized using a vortex, allowed to react in the dark at room temperature for $20 \mathrm{~min}$, after which time absorbance was measured at $517 \mathrm{~nm}$. Astaxanthin was used as a reference standard (curve from 10 to $250 \mu \mathrm{g} / \mathrm{mL}$ ). The results were expressed in Trolox micromoles per gram of extract ( $\mu \mathrm{mol}$ Trolox/g extract) and as $\mathrm{IC}_{50}$ in $\mu \mathrm{g} / \mathrm{mL}$, (concentration of infusion or standard in $\mu \mathrm{g} / \mathrm{mL}$ required to inhibit $50 \%$ of DPPH radical present in solution, as reported in [32,33]). A Synergy HTX Multi-Mode Microplate Reader (BioTek Instruments Inc., Winoosky, VT, USA) was used.

\subsubsection{ABTS Bleaching Capacity}

The capturing capacity of the $\mathrm{ABTS}^{\bullet+}$ radical was evaluated by the decolorization method developed by Re et al. (1999) and modified by Kuskoski et al. (2004) [34]. A solution of $7 \mathrm{mM}$ ABTS (2,2'-azino-bis (3-ethylbenzothiazoline-6-sulphonic acid)) in deionized water and a solution of $2.45 \mathrm{mM}$ potassium persulfate in water was prepared. Both solutions were mixed in a 1:1 ratio $(v / v)$ and incubated for $16 \mathrm{~h}$ in the dark for the formation of the radical $\mathrm{ABTS}^{\bullet+}$ by the oxidation of $\mathrm{ABTS}$ with potassium persulfate at room temperature. Then, to $20 \mu \mathrm{L}$ of the extract or standard to be measured (curve from 10-250 $\mu \mathrm{g} / \mathrm{mL}$ ), $200 \mu \mathrm{L}$ of the previously ABTS $^{\bullet+}$ solution (adjusted with $80 \%$ methanol to an absorbance of $0.70 \pm 0.02$ ) was added, mixed using a vortex mixer and subsequently allowed to react in darkness at room temperature [35]. The absorbance was then measured at $765 \mathrm{~nm}$ after $6 \mathrm{~min}$ of reaction, and astaxanthin was used as a reference standard (curve from 10-250 $\mu \mathrm{g} / \mathrm{mL}$ ). The results were expressed as TEAC, in Trolox micromoles per gram of extract ( $\mu \mathrm{mol}$ Trolox/g extract) and also as $\mathrm{IC}_{50}$ in $\mu \mathrm{g} \cdot \mathrm{mL}^{-1}$, (concentration of infusion or standard in $\mu \mathrm{g} \cdot \mathrm{mL}^{-1}$ required to inhibit $50 \%$ of DPPH radical present in solution) [32,33]. A Synergy HTX Multi-Mode Microplate Reader (BioTek Instruments Inc., Winoosky, VT, USA) was used. 


\subsubsection{Ferric Reduction Antioxidant Power Test (FRAP)}

For the FRAP test, the methodology described by Benzie and Strain [32,36] was performed with some modifications. Briefly, a buffer solution made of $\mathrm{CH}_{3} \mathrm{Nax}_{3} \mathrm{H}_{2} \mathrm{O}$ $3.1 \% / \mathrm{CH}_{3} \mathrm{COOH}$ (glacial) $16 \%$ dissolved in water plus $20 \mathrm{mM} \mathrm{FeCl}_{3}$ in aqueous solution $\mathrm{HCl} 0.02 \mathrm{M}$ and $10 \mathrm{mM}$ TPTZ dissolved in absolute ethanol was prepared. The working solution corresponded to a mixture of one volume of buffer with one volume of $\mathrm{FeCl}_{3}$ and 11 volumes of ethanol. The working solution $(290 \mu \mathrm{L})$ was mixed with $10 \mu \mathrm{L}$ of the standard Trolox (from 10 to $250 \mu \mathrm{g} / \mathrm{mL}$ ) in a well of the microplate in quintuplicate, and a curve was prepared measuring the absorbance of the colored Fe-TPTZ complex at $593 \mathrm{~nm}$ after $5 \mathrm{~min}$. Then, absorbance values (in quintuplicate) of strain extracts (10 $\mu \mathrm{L}$, at a concentration: $2 \mu \mathrm{g} / \mathrm{mL}$ ) were replaced in the Trolox standard curve equation [32,35]. The results were expressed as Trolox equivalents (TE) in Trolox micromoles per gram of extract ( $\mu \mathrm{mol}$ Trolox/g extract). A Synergy HTX Multi-Mode Microplate Reader (BioTek Instruments Inc., Winoosky, VT, USA) was used.

\subsection{Cholinesterases' (ChE) Enzyme Inhibitory Activity}

The inhibitory activity of these important enzymes was measured thorough Ellman's method, as stated previously [32,37]. Briefly, DTNB was dissolved in buffer Tris- $\mathrm{HCl}$ at $\mathrm{pH}$ 8.0 containing $0.1 \mathrm{M} \mathrm{NaCl}$ and $0.02 \mathrm{M} \mathrm{MgCl}_{2}$. Then, a filtered sample solution dissolved in deionized water ( $50 \mu \mathrm{L}$, the final concentration of the plate ranged from 0.05 to $25 \mu \mathrm{g} / \mathrm{mL}$ ) was mixed with $125 \mu \mathrm{L}$ of 5-dithio-bis (2-nitrobenzoic) acid (DTNB), acetylcholinesterase (AChE), or butyrylcholinesterase (BuChE) solution $(25 \mu \mathrm{L})$ dissolved in Tris- $\mathrm{HCl}$ buffer at $\mathrm{pH} 8.0$ in a 96-well microplate and incubated for $15 \mathrm{~min}$ at $25^{\circ} \mathrm{C}$. Initiation of reaction was performed by the addition of acetyl-thiocholine iodide (ATCI) or butyryl-thiocholine chloride (BTCl) $(25 \mu \mathrm{L})$. In addition, a blank was prepared by adding the solution sample to all reagents without the enzyme(s) (AChE or BuChE) solutions. The sample and blank absorbances were then read at $405 \mathrm{~nm}$ after $10 \mathrm{~min}$ of incubation at $25^{\circ} \mathrm{C}$. The absorbance of the sample was subtracted from that of the blank and the cholinesterase inhibitory capacity was expressed as $\mathrm{IC}_{50}(\mu \mathrm{g} / \mathrm{mL})$. A Synergy HTX Multi-Mode Microplate Reader (BioTek Instruments Inc., Foster City, CA, USA) was used. Three experiments were performed in triplicate in each case and the values are reported as the mean $\pm \mathrm{SD}$. Galanthamine was used as positive control.

\subsection{UHPLC PDA-MS Instrument}

A Thermo Scientific Ultimate 3000 UHPLC with PDA detector controlled by Chromeleon 7.2 Software (Thermo Fisher Scientific, Waltham, MA, USA) hyphenated with a Thermo high resolution Q-Exactive focus mass spectrometer (Thermo, Bremen, Germany) were used for analysis. The chromatographic system was coupled to the MS using a type II heated electrospray ionization source. Nitrogen obtained (purity $>99.999 \%$ ) from a nitrogen generator (Genius NM32LA, Peak Scientific, Billerica, MA, USA) was employed as both the collision and damping gas. Mass calibration for Orbitrap was performed once a day, in both negative and positive modes, to ensure working mass $5 \mathrm{ppm}$ of accuracy. For positive mode, a mixture of caffeine $(1 \mathrm{mg} / \mathrm{mL}, 20 \mu \mathrm{L})$ and N-butylamine $(1 \mathrm{mg} / \mathrm{mL}$, $100 \mu \mathrm{L})$ was used, while a mixture of sodium dodecyl sulfate $(1 \mathrm{mg} / \mathrm{mL}, 100 \mu \mathrm{L})$ and taurocholic acid sodium salt $(1 \mathrm{mg} / \mathrm{mL}, 100 \mu \mathrm{L})$ (Sigma-Aldrich, Darmstadt, Germany) was used for negative mode. In addition, Ultramark 1621 (Alpha Aezar, Stevensville, MI, USA) was used as the reference compound $(1 \mathrm{mg} / \mathrm{mL}, 100 \mu \mathrm{L})$. These compounds were dissolved in a mixture of acetic acid $(100 \mu \mathrm{L})$, acetonitrile $(5 \mathrm{~mL})$, water: methanol (1:1) ( $5 \mathrm{~mL}$ ) (Merck, Santiago, Chile), and $20 \mu \mathrm{L}$ of the mixture infused using a Chemyx Fusion (Thermo Fisher Scientific, Bremen, Germany) $100 \mu \mathrm{L}$ syringe pump and mass calibration performed every day. The strain extracts were redissolved in methanol (concentration: $2 \mathrm{mg} / \mathrm{mL}$ ), filtered (PTFE filter, Merck) and $10 \mu \mathrm{L}$ were injected in the UHPLC instrument for UHPLC-MS analysis. 


\subsection{Quantitative HPLC of Carotenoids}

Liquid chromatography on an Acclaim UHPLC C-18 column (length $150 \mathrm{~mm} \times 4.6 \mathrm{~mm}$ ID, $2.5 \mu \mathrm{m}$, Thermo Fisher Scientific, Bremen, Germany) as reported previously. The mobile phases were $1 \%$ formic aqueous solution (A), methanol $1 \%$ formic acid (B), and acetonitrile $1 \%$ formic acid $(\mathrm{C})$. The gradient program time $(\mathrm{min})(\% \mathrm{~B}, \mathrm{C})$ was: $(0.00,18,75) ;(5.00$, $18,75) ;(15.00,40,60) ;(20.00,100)$; and 12 min for column equilibration. A curve was performed with astaxanthin (Sigma Aldrich, Santiago, Chile), covering six points, with standard solutions from 0.1 to $1 \mu \mathrm{g} / \mathrm{mL}, \mathrm{R}^{2}=0.9999$ (LOD: 3.22 LOQ $10.43 \mu \mathrm{g} / \mathrm{L}$, standard recovery rate of astaxanthin: $99.51 \%$ ). The flow rate was set at $1.00 \mathrm{~mL} \mathrm{~min}^{-1}$, and the injection volume was $10 \mu \mathrm{L}$. Standards and extracts dissolved in methanol were kept at $10^{\circ} \mathrm{C}$ in the autosampler. The detection wavelengths were 280, 330, 515 and $490 \mathrm{~nm}$, and the diode array detector was recorded from 200 to $800 \mathrm{~nm}$ for peak characterization. For quantitative HPLC analysis, each sample was run in triplicate and the peak was monitored through DAD detector at $490 \mathrm{~nm}$ wavelength, similar to that previously reported for other extremophiles $[17,38]$.

\subsection{MS Parameters}

The HESI II and Orbitrap spectrometer parameters were optimized as previously reported by [39]. We could use HESI instead of APCI for the fast detection of carotenoids compounds. The HESI II parameters were optimized as follows: sheath gas flow rate of 35 units; aux. gas unit flow rate of 12 ; capillary temperature of $320^{\circ} \mathrm{C}$; aux gas heater temperature of $500{ }^{\circ} \mathrm{C}$; spray voltage of $3700 \mathrm{~V}$ (for ESI+); and S tube lens RF level of 55 , as reported previously. Full scan data in both positive and negative were acquired at a resolving power of 70,000 FWHM (full width half maximum) at $m / z 200$. For the compounds of interest, a scan range of $m / z 100-1000$ was chosen; the automatic gain control (AGC) was set at $3 \times 10^{6}$ and the injection time was set to $200 \mathrm{~ms}$. Scan-rate was set at 2 scans s$^{-1}$. External calibration was performed using a calibration solution in positive and negative modes before each sample series. In addition to the full scan acquisition method, for confirmation purposes, a targeted MS/MS analysis was performed using the mass inclusion list and expected retention times of the target analytes, with a $30 \mathrm{~s}$ time window, with the Orbitrap spectrometer operating both in positive and negative mode at 17,500 FWHM $(m / z$ 200). Collision energy (HCD cell) was operated at $35 \mathrm{kv}$. Detection was based on calculated exact mass and on retention time of target compounds, presented in Table 1.

\subsection{HaCaT Cell Culture}

Immortalized human epidermal keratinocytes $\mathrm{HaCaT}$ cells were purchased in AddexBio catalog number \#T0020001. The culture was carried out in $75 \mathrm{~cm}^{2}$ bottles with complete culture medium (Dulbecco's modified Eagle medium (DMEM, Gibco Thermo fisher, Santiago, Chile) supplemented with 10\% fetal bovine serum (FBS; Gibco) and 1\% penicillin G-streptomycin (Gibco) at $37{ }^{\circ} \mathrm{C}$ in a humid atmosphere with $5 \% \mathrm{CO}_{2}$. After reaching $70-80 \%$ confluence, the $\mathrm{HaCaT}$ cells were recovered with $0.25 \%$ trypsin- $1 \mathrm{mM}$ EDTA and resuspended in DMEM to inactivate the trypsin. The cells were cultured again in a 96-well plate for the MTT assay. 
Table 1. UHPLC-Q-OT-MS/MS data of haloarchaea strains: Te Se-85, Te Se-86, ALT-23, TeSe-41, TeSe-51 and TeSe-89. Peak numbers refer to Figure 3.

\begin{tabular}{|c|c|c|c|c|c|c|c|c|}
\hline$\underset{\#}{\text { Peak }}$ & $\begin{array}{l}\mathbf{R t} \\
\text { (min.) }\end{array}$ & $\underset{(\mathrm{nm})}{\lambda \max }$ & Tentative Identification & $\begin{array}{l}\text { Molecular } \\
\text { Formula }\end{array}$ & $\begin{array}{l}\text { Theoretical } \\
\text { Mass }(m / z)\end{array}$ & $\begin{array}{l}\text { Measured } \\
\text { Mass }(m / z)\end{array}$ & 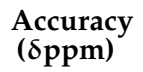 & $\begin{array}{l}\text { MS }^{\mathbf{n}} \text { ions } \\
(\mathrm{m} / \mathrm{z})\end{array}$ \\
\hline 1 & 2.75 & & Unknown & - & & 156.04250 & & \multirow{22}{*}{$\begin{array}{l}420.30792 \\
665.54810, \\
681.12321 \\
443.30157, \\
723.32542, \\
682.55681, \\
577.12548 \\
682.55310\end{array}$} \\
\hline 2 & 2.75 & & Unknown & - & & 220.11290 & & \\
\hline 3 & 2.44 & & Unknown & - & & 394.29160 & & \\
\hline 4 & 2.75 & & $\begin{array}{l}\text { Possibly glucosyl } \\
\text { bacterioruberin derivative }\end{array}$ & $\mathrm{C}_{55} \mathrm{H}_{83} \mathrm{O}_{8}$ & & 871.61510 & & \\
\hline 5 & 4.45 & $\begin{array}{c}318,388,466,495 \\
528\end{array}$ & Bacterioruberin & $\mathrm{C}_{50} \mathrm{H}_{74} \mathrm{O}_{4}$ & 740.57436 & 740.59998 & 34.59 & \\
\hline 6 & 4.92 & $387,466,492,525$ & 5-cis-Bacterioruberin & $\mathrm{C}_{50} \mathrm{H}_{74} \mathrm{O}_{4}$ & 740.57436 & 740.60022 & 34.91 & \\
\hline 7 & 5.91 & $387,466,492,525$ & 9-cis-Bacterioruberin & $\mathrm{C}_{50} \mathrm{H}_{74} \mathrm{O}_{4}$ & 740.57436 & 740.60052 & 35.32 & \\
\hline 8 & 6.31 & $387,466,488,525$ & 13-cis-Bacterioruberin & $\mathrm{C}_{50} \mathrm{H}_{74} \mathrm{O}_{4}$ & 740.57436 & 740.59991 & 34.50 & \\
\hline 9 & 7.02 & $387,466,488,525$ & 5-cis-26-cis-Bacterioruberin & $\mathrm{C}_{50} \mathrm{H}_{74} \mathrm{O}_{4}$ & 740.57436 & 740.60034 & 34.50 & \\
\hline 10 & 8.04 & $387,466,488,525$ & 9-cis-26-cis-Bacterioruberin & $\mathrm{C}_{50} \mathrm{H}_{74} \mathrm{O}_{4}$ & 740.57436 & 740.599991 & 34.60 & \\
\hline 11 & 9.52 & $\begin{array}{c}318,369,388,465 \\
494,528\end{array}$ & Monoanhidrobacterioruberin & $\mathrm{C}_{50} \mathrm{H}_{74} \mathrm{O}_{3}$ & 722.56680 & 722.58799 & 29.94 & \\
\hline 12 & 11.26 & $\begin{array}{c}369,385,465,492, \\
524\end{array}$ & $\begin{array}{c}\text { 5-cis- } \\
\text { Monoanhidrobacterioruberin }\end{array}$ & $\mathrm{C}_{50} \mathrm{H}_{74} \mathrm{O}_{3}$ & 722.56680 & 722.58820 & 29.61 & \\
\hline 13 & 11.61 & $\begin{array}{c}318,369,388,459 \\
484,516\end{array}$ & $\begin{array}{l}\text { Reduced monoanhidrobac- } \\
\text { terioruberin }\end{array}$ & $\mathrm{C}_{50} \mathrm{H}_{76} \mathrm{O}_{3}$ & 724.57945 & 724.60364 & 33.38 & \\
\hline 14 & 12.09 & $\begin{array}{c}318,369,388,465 \\
495,528\end{array}$ & $\begin{array}{l}\text { 9-cis- } \\
\text { monoanhidrobacterioruberin }\end{array}$ & $\mathrm{C}_{50} \mathrm{H}_{74} \mathrm{O}_{3}$ & 722.56680 & 722.58856 & 30.11 & \\
\hline 15 & 12.94 & $\begin{array}{c}318,369,388,465 \\
495,528\end{array}$ & $\begin{array}{c}13-c i s- \\
\text { monoanhidrobacterioruberin }\end{array}$ & $\mathrm{C}_{50} \mathrm{H}_{74} \mathrm{O}_{3}$ & 722.56680 & 722.58826 & 29.69 & \\
\hline 16 & 13.51 & $\begin{array}{c}340,377 \\
458,483,515\end{array}$ & $\begin{array}{l}\text { Reduced monoanhidrobac- } \\
\text { terioruberin }\end{array}$ & $\mathrm{C}_{50} \mathrm{H}_{76} \mathrm{O}_{3}$ & 724.57945 & 724.60413 & 34.06 & \\
\hline 17 & 15.31 & $\begin{array}{c}370,389,460,494 \\
527\end{array}$ & Bisanhidrobacterioruberin & $\mathrm{C}_{50} \mathrm{H}_{72} \mathrm{O}_{2}$ & 704.55323 & 704.57642 & 32.91 & \\
\hline 18 & 15.84 & $\begin{array}{c}370,386,460,491 \\
524\end{array}$ & $\begin{array}{c}\text { 5-cis- } \\
\text { Bisanhidrobacterioruberin }\end{array}$ & $\mathrm{C}_{50} \mathrm{H}_{72} \mathrm{O}_{2}$ & 704.55323 & 704.57617 & 32.55 & \\
\hline 19 & 16.26 & $370,386,464,489$ & $\begin{array}{c}\text { 9-cis- } \\
\text { Bisanhidrobacterioruberin }\end{array}$ & $\mathrm{C}_{50} \mathrm{H}_{72} \mathrm{O}_{2}$ & 704.55323 & 704.57660 & 33.16 & \\
\hline 20 & 16.86 & $\begin{array}{c}370,388,459,485 \\
517\end{array}$ & $\begin{array}{c}\text { Reduced } \\
\text { Bisanhidrobacterioruberin }\end{array}$ & $\mathrm{C}_{50} \mathrm{H}_{74} \mathrm{O}_{2}$ & 706.56888 & 706.59619 & 38.65 & \\
\hline 21 & 17.83 & 17.83 & Unknown & - & - & 475.44403 & & \\
\hline 22 & & & Unknown & - & - & 708.60803 & & \\
\hline
\end{tabular}

\#: number $\mathrm{MS}^{\mathrm{n}}$ : fragment ions.

\subsection{Cellular Viability and Stimulation of $\mathrm{HaCaT}$ Cells}

For this test, the biomass (strain material) of the haloarchaea was obtained by centrifugation at 10,000 rpm for $15 \mathrm{~min}$ from a liquid culture to $25 \%$ total salts of the medium $\mathrm{MH}$. The strain Halorubrum tebenquichense Te Se-86 was selected for the testing the stimulation of $\mathrm{HaCaT}$ cells. The biomass obtained after centrifugation was suspended in complete culture medium for $\mathrm{HaCaT}$ at $1 \mathrm{~g} / \mathrm{mL}$. Then, the solution served as the stock solution to prepare serial dilutions from 1000 to $15 \mu \mathrm{g} / \mathrm{mL}$. To obtain the effects of strain biomass on the cellular viability, we performed an MTT assay. For this, $\mathrm{HaCaT}$ cells were stimulated with different concentrations of dry biomass, obtaining a dose-response curve, including concentrations of $1000,500,250,125,62.5,31,15 \mu \mathrm{g} / \mathrm{mL}$ at different durations of stimulation of $6,24,48$ and $72 \mathrm{~h}$. The MTT assay began $2 \mathrm{~h}$ before the end of the stimulation, adding MTT solution dissolved in phosphate saline buffer $1 \times$ at a final concentration of $0.5 \mathrm{mg} / \mathrm{mL}$. After $2 \mathrm{~h}$, the culture medium was removed and $50 \mu \mathrm{L}$ of dimethylsulfoxide (DMSO) was added, the solution was incubated for $10 \mathrm{~min}$ at $37^{\circ} \mathrm{C}$ to dissolve the formazan crystals, and finally the viability was measured in a microplate reader at $545 \mathrm{~nm}$. Complete medium was used in parallel as a vehicle and 10\% DMSO was used as the control.

\subsection{Oxidative Stress: Nitrite $\left(\mathrm{NO}_{2}{ }^{-}\right)$Concentration Assay}

The Griess Reagent Kit for Nitrite Determination (Invitrogen ${ }^{\mathrm{TM}}$, Carlsbad, CA, USA) was used according to the manufacturer's instructions to measure nitrite $\left(\mathrm{NO}_{2}{ }^{-}\right)$, one of two primary stable and nonvolatile breakdown products of nitric oxide (NO). The procedure was performed 6 and $24 \mathrm{~h}$ after the end of the incubation of HaCaT cells. The level of nitrite in the cell culture medium was analyzed spectrophotometrically. The 
absorbance was measured at $548 \mathrm{~nm}$ using a multi-well plate reader (BioTek TM, Epoch, BioTek Instruments Inc., Winoosky, VT, USA). In parallel, complete medium was used as a vehicle and control.

\subsection{Docking Assays of Carotenoids in ChE Enzymes}

Docking simulations were carried for each carotenoid fragment. The geometries and partial charges of every fragment were fully optimized using the semi-empirical method for quantum calculation, Austin Model 1 (AM1 and docking calculation performed with Gaussian 09W software [40].

\section{Results and Discussion}

\subsection{Identification of Haloarchaea Strain}

In this study, six new haloarchaea are reported, which have an orange-red color due to their high carotenoids content. The haloarquea strains are Gram-negative stained, nonmotile and have irregular disc-shaped forms. The colonies are orange-red colored in agar plates containing $25 \%(w / v)$ total salts. In liquid medium, the pigment culture change to an intense orange-red color after $72 \mathrm{~h}$ of incubation (Figure 1). The analysis of the almost complete 16S rRNA gene sequence indicated that Te Se-85 and Te Se-86 strains are designated as the Halorubrum genus because they matched by $100 \%$ and $99.8 \%$, respectively, with the characteristics of the reference strain Halorubrum tebenquichense ALT-6. The isolates ALT-23, TeSe-41, TeSe-51 are the closest to the genus Haloarcula. TeSe-89 strain showed 97.83\% match with the identity of Haloarcula hispanica while the strains ALT-23; TeSe-41 and TeSe-51 showed a resemblance of $96.59 \%, 97.95 \%$ and $98.50 \%$ with Haloarcula hispanica, Haloarcula salaria and Haloarcula japonica, respectively [41]. The distance tree is plotted for the new sequences and the 16S rRNA sequences of other related haloarchaea (Figure 2).

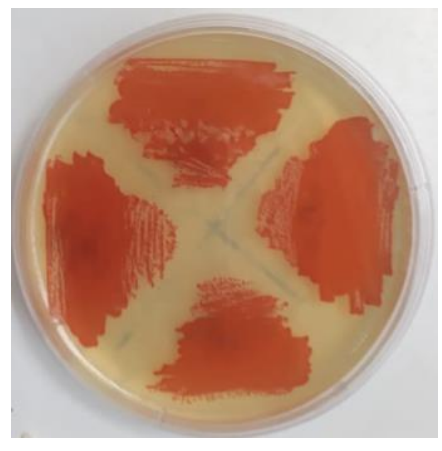

(A)

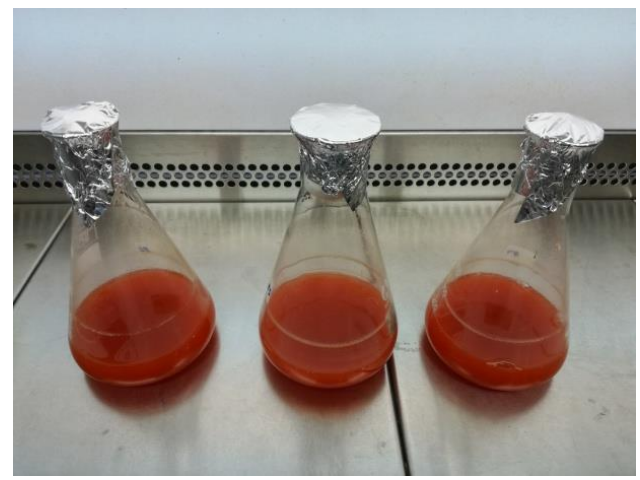

(B)

Figure 1. Orange-red haloarchaea colonies. (A) The colonies are orange in agar plates containing $25 \%(w / v)$ total salts (B) Culture liquid medium $\mathrm{MH}$ at $25 \% w / v$, so the pigment culture changes to an intense red color after $72 \mathrm{~h}$ of incubation at $40{ }^{\circ} \mathrm{C}$ and $120 \mathrm{rpm}$.

The evolutionary history was inferred by using the maximum likelihood method and the general time reversible model (Figure 2) [42]. The percentage of trees in which the associated taxa clustered together is shown next to the branches. Initial trees for the heuristic search were obtained automatically by applying the neighbor-join and BioNJ algorithms to a matrix of pairwise distances estimated using the maximum composite likelihood (MCL) approach, and then selecting the topology with superior log likelihood value. The tree is drawn to scale, with branch lengths measured in the number of substitutions per site. Evolutionary analyses were conducted in MEGA X [24]. The horizontal bar at the base of the figure represents 0.05 substitutions per nucleotide site. The percentage of trees in which the associated taxa clustered together is shown next to the branches, using a bootstrap of 500 . 


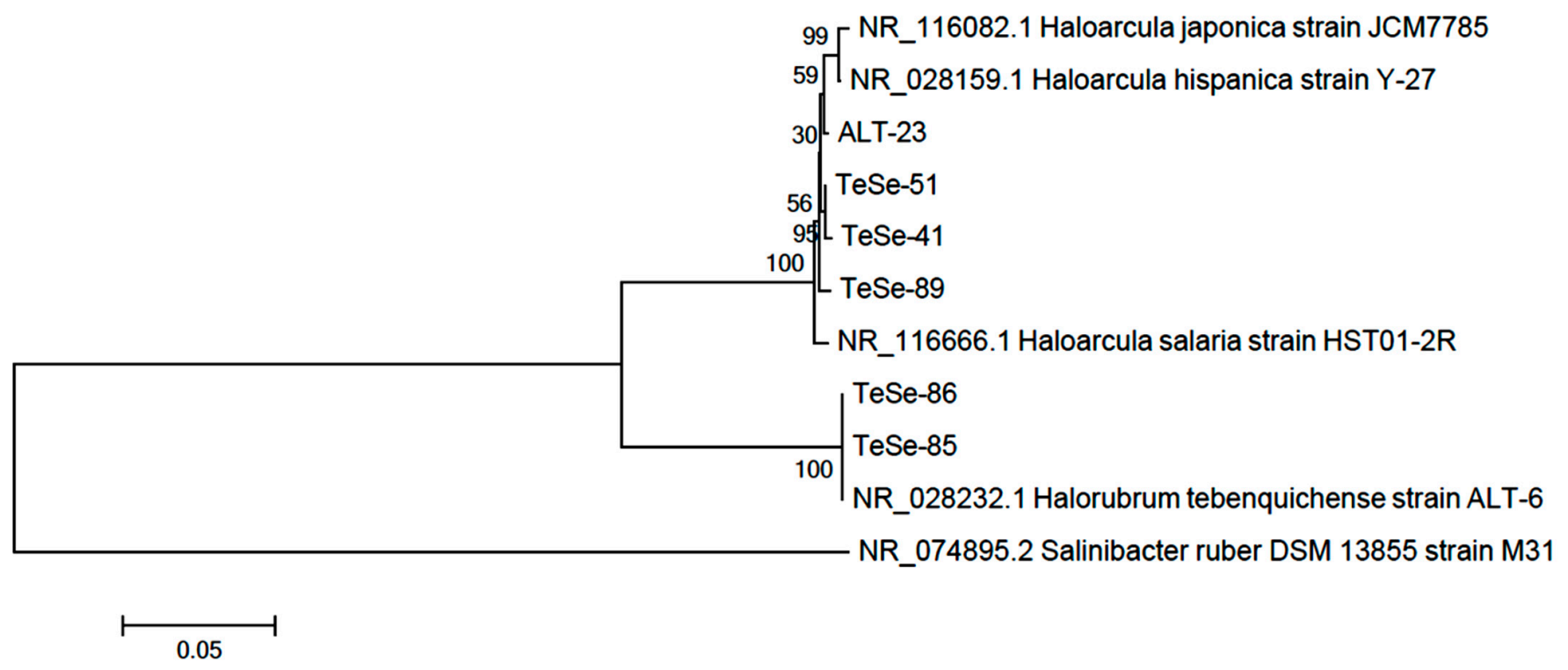

Figure 2. Evolutionary analyses of haloarchaea.

The GenBank accessions for the 16S rRNA gene sequences are: MZ576846 (TeSe-89); MZ576847 (TeSe- 86); MZ576848 (TeSe-85); MZ576849 (TeSe-51); MZ576850 (TeSe-41) and MZ576851 (ALT-23).

\subsection{Identification of the Carotenoids Compounds}

Sixteen compounds were identified or tentatively identified by means of high resolution Orbitrap mass spectrometry (Table 1, Figures 3 and 4). The fast identification of the compounds is explained below. Several compounds were identified as carotenoids, the responsible agents for the color of the strains. Peak 1 (Uv-max 318, 388, 466, 495, $528 \mathrm{~nm}$ ) with a pseudomolecular ion at $m / z 740.59998$ was identified as bacterioruberin $\left(\mathrm{C}_{50} \mathrm{H}_{74} \mathrm{O}_{4}\right)$ [43], a potent antioxidant. Peaks 6, 7 and 8 with similar molecular mass were identified as isomers of the latter with cis double bonds (5-cis-bacterioruberin, 9cis-bacterioruberin and 13-cis-bacterioruberin) [9], respectively (Figure 3). Peaks 9 and 10 with molecular ions at $m / z 740.60034$ and 740.59999 were identified as 5-cis-26-cisbacterioruberin and 9-cis-22-cis-bacterioruberin $\left(\mathrm{C}_{50} \mathrm{H}_{74} \mathrm{O}_{4}\right)$, respectively. Peak 11 with UV max at 318, 369, 388, 465, 494, $528 \mathrm{~nm}$ and ion at $\mathrm{m} / \mathrm{z} 722.58799$ was identified as the dehydrated compound mono-anhidrobacterioruberin $\left(\mathrm{C}_{50} \mathrm{H}_{74} \mathrm{O}_{3}\right)$ [44], while peaks 12, 14 and 15 were identified as the isomers of the latter, 5-cis-monoanhidrobacterioruberin, 9-cis-monoanhidrobacterioruberin and 13-cis-monoanhidrobacterioruberin, respectively. Peaks 13 and 16 with ions at $m / z 724.60364$ were identified as reduction products of peak $11\left(\mathrm{C}_{50} \mathrm{H}_{76} \mathrm{O}_{3}\right)$. In the same manner, peak 17 with an ion at $m / z 704.57642$ was identified as the di-dehydrated carotene bisanhidrobacterioruberin $\left(\mathrm{C}_{50} \mathrm{H}_{72} \mathrm{O}_{2}\right)$ [44], peaks 18 and 19 were identified as 5-cis-bisanhidrobacterioruberin and 9-cis-bisanhidrobacterioruberin $\left(\mathrm{C}_{50} \mathrm{H}_{72} \mathrm{O}_{2}\right)$ [45], respectively, and finally, peak 20 with an ion at $\mathrm{m} / \mathrm{z} 706.59619$ was identified as reduced bisanhidrobacterioruberin. 


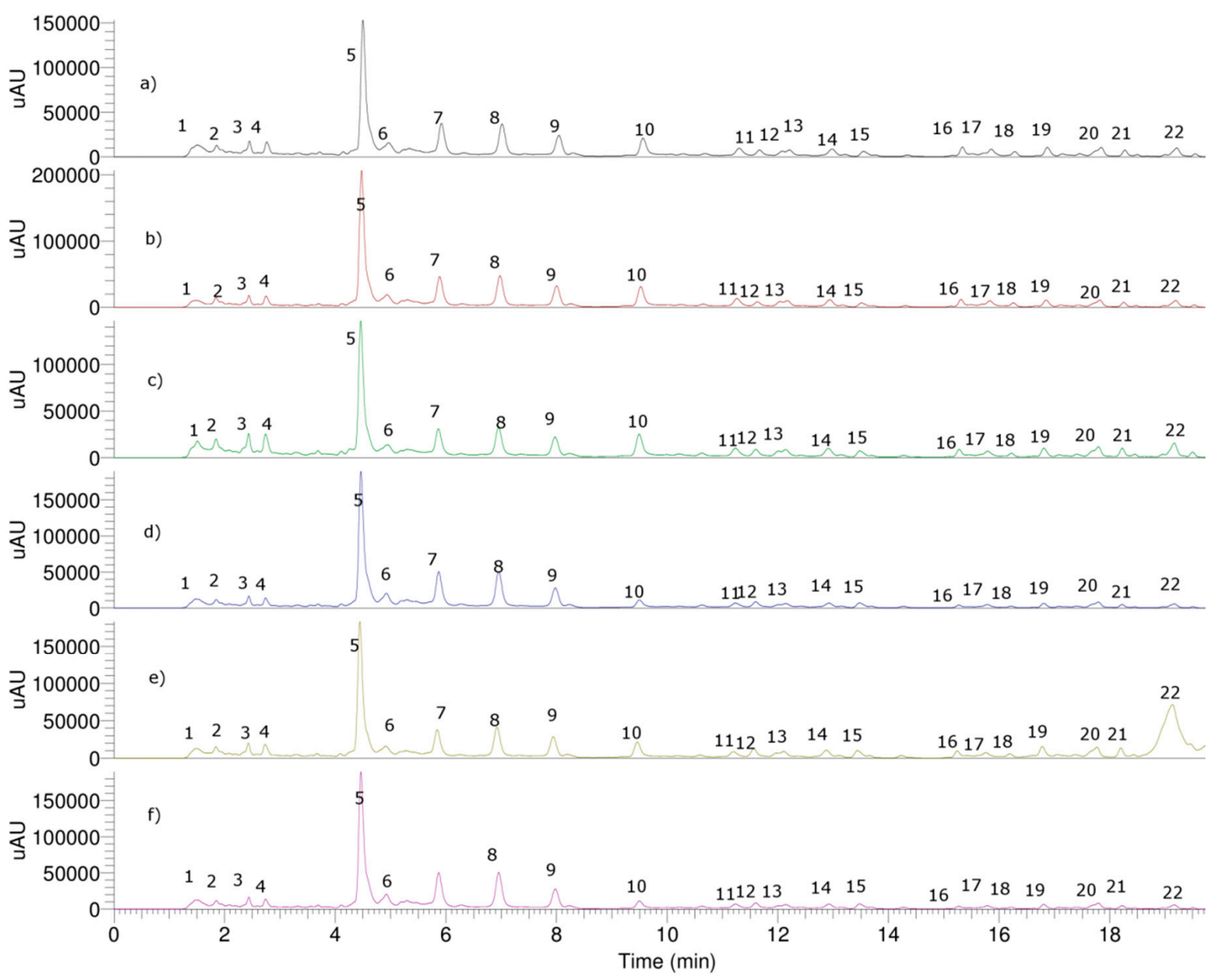

Figure 3. (a-f). HPLC-DAD chromatograms at $490 \mathrm{~nm}$ of haloarchaea strains: Te Se-85, Te Se-86, ALT-23, TeSe-41, TeSe-51 and TeSe- 89 .

3.3. Total Phenols, Carotenoids Content, Enzyme Inhibitory Activity and Antioxidant Properties of Haloarchaea

In the DPPH assays, generally, extracts for these haloarchaea showed considerable antioxidant activity [9]. The DPPH scavenging activity of our strains was shown to be similar to that of the extremophiles Aquisalibacillus elongatus MB592 [17] (80 percent inhibition of DPPH radical at 5-30 $\mathrm{g} / \mathrm{mL}$ ). The haloarchaea Halorubrum tebenquichense Te Se-86 showed the highest radical trapping ability (59.14 $\pm 9.54 \mu \mathrm{mol}$ Trolox/g extract, $\left(\mathrm{IC}_{50}=2.95 \pm 0.02 \mu \mathrm{g} / \mathrm{mL}\right)$, which is close to that exhibited by Haloarcula hispanica [33], followed by Halorubrum tebenquichense TeSe-85 (55.43 $\pm 3.26 \mu \mathrm{mol}$ Trolox/g extract, $\left.\mathrm{IC}_{50}=4.73 \pm 0.02 \mu \mathrm{g} / \mathrm{mL}\right) ;$ Haloarcula sp. TeSe-41 (41.11 $\pm 6.02 \mu \mathrm{mol}$ Trolox $/ \mathrm{g}$ extract $)$ and Haloarcula sp. ALT-23 (39.84 $\pm 6.21 \mu \mathrm{mol}$ Trolox/g extract). ABTS radical bleaching and reducing power FRAP assay showed the same trend, which is in accordance with the carotenoid and phenolic content found (Te Se-86 > Te Se-85 > TeSe-41 > ALT-23 > TeSe-51 > TeSe-89, Table 2). The total carotenoids compounds range from $950.2 \pm 15.5 \mu \mathrm{g}$ astaxanthin/g dry weight (Te Se-86) to $412.39 \pm 19.1 \mu \mathrm{g}$ astaxanthin/g dry weight (TeSe-89), as measured by spectrophotometry (Table 2). 


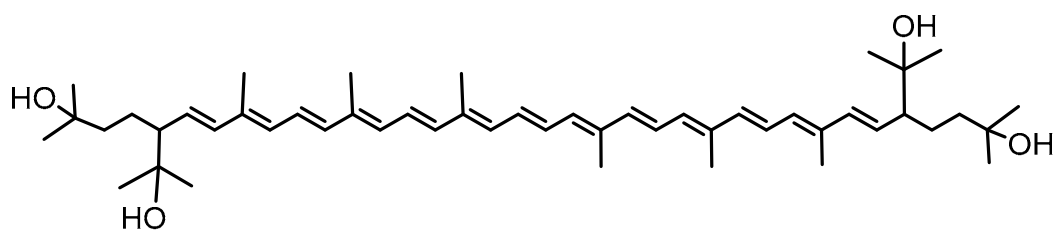

Peak 5, Bacterioruberin
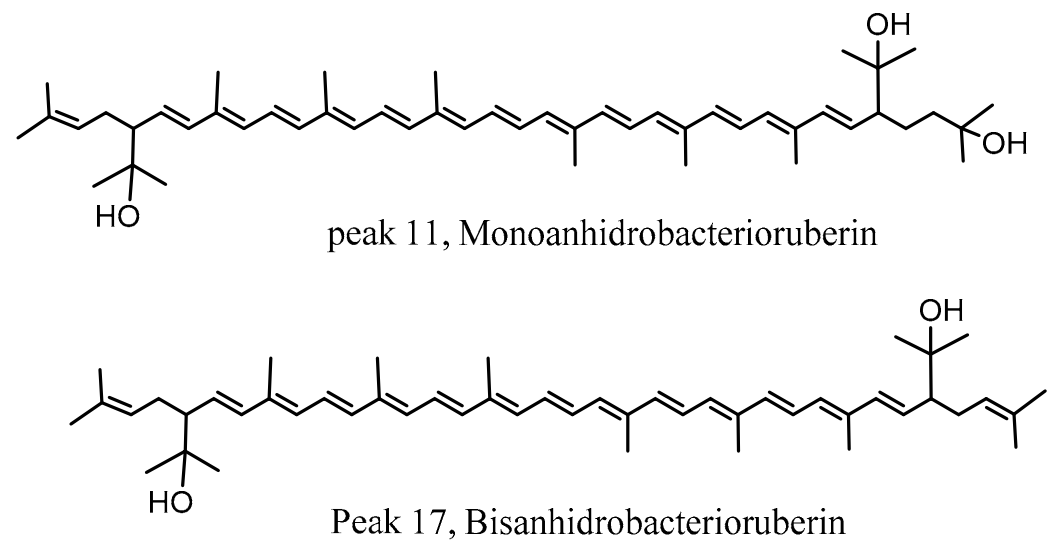

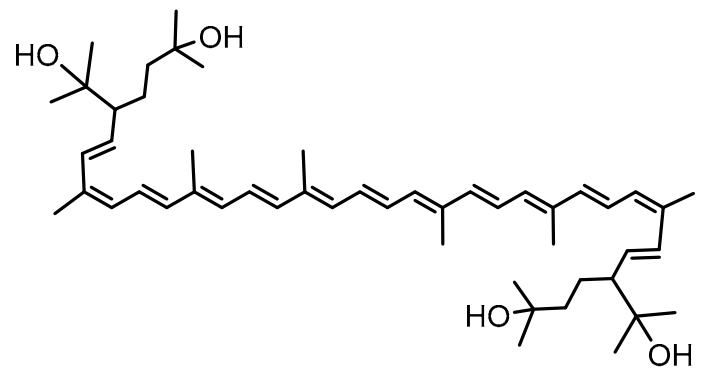

Peak 9, 5-cis-26-cis-Bacterioruberin

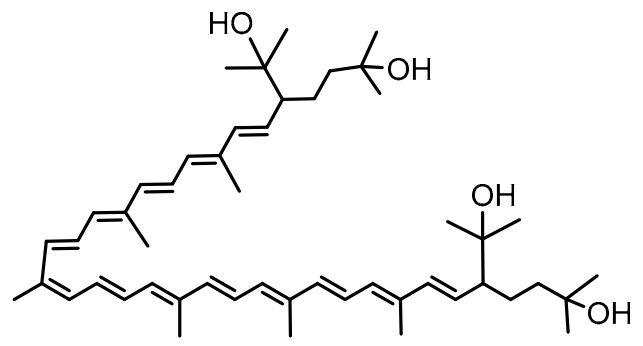

Peak 8, 13-cis-Bacterioruberin

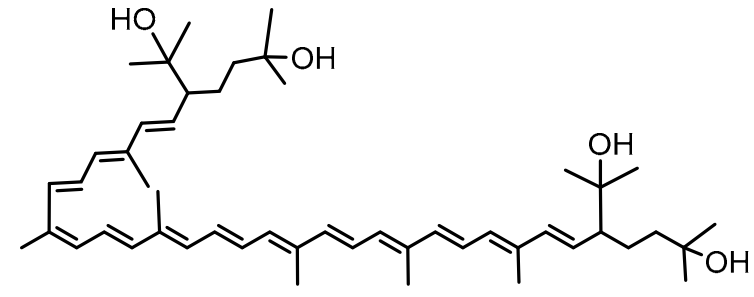

Peak 7, 9-cis-Bacterioruberin

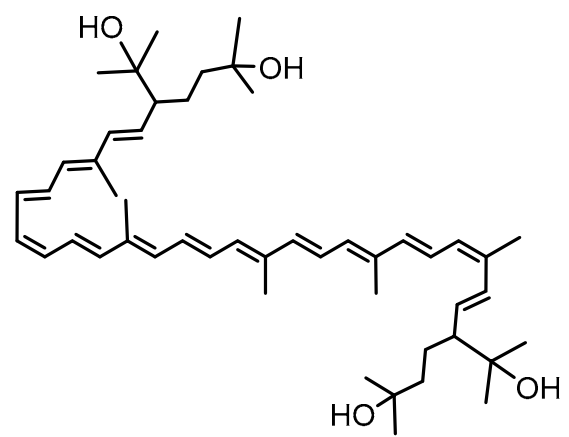

Peak 10, 9-cis-26-cis-Bacterioruberin

Figure 4. Structures of some representative carotenoids compounds found in haloarchaea. 
Table 2. Scavenging of the 1,1-diphenyl-2-picrylhydrazyl radical (DPPH), radical ABTS, (ABTS), total phenolic content (TPC), total carotenoid content (TCC) and cholinesterase inhibition capacity of six haloarchaea (Te Se-85, Te Se-86, ALT-23, TeSe-41, TeSe-51 and TeSe-89) from the II Region of Chile. $(n=5)$.

\begin{tabular}{|c|c|c|c|c|c|c|c|}
\hline Sample & $\mathrm{DPPH}^{\mathrm{a}}$ & ABTS $^{b}$ & FRAP $^{c}$ & TPC $^{d}$ & TCC $^{\mathrm{e}}$ & $\mathrm{ACHe}^{\mathrm{f}}$ & $\mathrm{BuCHe}^{\mathrm{f}}$ \\
\hline Te Se-85 & $\begin{array}{c}55.43 \pm 3.26^{\mathrm{i}} \\
\left(\mathrm{IC} \mathrm{C}_{50}=4.73 \pm 0.02\right. \\
\mu \mathrm{g} / \mathrm{mL})\end{array}$ & $\begin{array}{c}473.50 \pm 15.85 \\
\left(\mathrm{IC}_{50}=7.98 \pm 0.03\right. \\
\mu \mathrm{g} / \mathrm{mL})\end{array}$ & $878.07 \pm 11.60$ & $175.62 \pm 8.26$ & $714.4 \pm 11.5$ & $2.96 \pm 0.08$ & $2.39 \pm 0.09$ \\
\hline Te Se-86 & $\begin{array}{c}59.14 \pm 9.544^{\mathrm{i}} \\
\left(\mathrm{IC}_{50}=2.95 \pm 0.02\right. \\
\mu \mathrm{g} / \mathrm{mL})\end{array}$ & $\begin{array}{c}570.54 \pm 15.45 \\
\left(\mathrm{IC}_{50}=4.23 \pm 0.02\right. \\
\mu \mathrm{g} / \mathrm{mL})\end{array}$ & $1023.03 \pm 10.23$ & $199.32 \pm 7.54$ & $950.2 \pm 15.5$ & $4.24 \pm 0.10$ & $8.63 \pm 0.06$ \\
\hline ALT-23 & $\begin{array}{c}39.84 \pm 6.21 \mathrm{~h} \\
\left(\mathrm{IC}_{50}=8.83 \pm 0.03\right. \\
\mu \mathrm{g} / \mathrm{mL})\end{array}$ & $\begin{array}{c}342.46 \pm 10.95 \\
\left(\mathrm{IC}_{50}=12.12 \pm 0.04\right. \\
\mu \mathrm{g} / \mathrm{mL})\end{array}$ & $669.26 \pm 8.89$ & $136.63 \pm 5.22$ & $522.05 \pm 18.7^{\mathrm{k}, 1}$ & $7.89 \pm 0.04$ & $18.33 \pm 0.07$ \\
\hline TeSe-41 & $\begin{array}{c}41.11 \pm 6.02^{\mathrm{h}} \\
\left(\mathrm{IC}_{50}=6.25 \pm 0.01\right. \\
\mu \mathrm{g} / \mathrm{mL})\end{array}$ & $\begin{array}{c}376.38 \pm 12.06 \\
\left(\mathrm{IC}_{50}=9.32 \pm 0.02\right. \\
\mu \mathrm{g} / \mathrm{mL})\end{array}$ & $762.50 \pm 10.64$ & $146.19 \pm 6.27$ & $540.7 \pm 12.2^{1}$ & $2.57 \pm 0.04$ & $7.57 \pm 0.05$ \\
\hline TeSe-51 & $\begin{array}{c}26.13 \pm 3.25 \mathrm{~g} \\
\left(\mathrm{IC}_{50}=15.43 \pm 0.04\right. \\
\mu \mathrm{g} / \mathrm{mL})\end{array}$ & $\begin{array}{c}272.61 \pm 11.31^{\mathrm{j}} \\
\left(\mathrm{IC}_{50}=18.45 \pm 0.08\right. \\
\mu \mathrm{g} / \mathrm{mL})\end{array}$ & $479.27 \pm 9.37$ & $98.64 \pm 6.35$ & $512.63 \pm 13.5^{\mathrm{k}}$ & $7.80 \pm 0.03$ & $3.52 \pm 0.04$ \\
\hline TeSe-89 & $\begin{array}{c}23.10 \pm 4.68 \mathrm{~g} \\
\left(\mathrm{IC}_{50}=23.19 \pm 0.04\right. \\
\mu \mathrm{g} / \mathrm{mL})\end{array}$ & $\begin{array}{c}250.66 \pm 18.70 \mathrm{j} \\
\left(\mathrm{IC}_{50}=34.72 \pm 0.06\right. \\
\mu \mathrm{g} / \mathrm{mL})\end{array}$ & $396.56 \pm 21.11$ & $79.85 \pm 5.48$ & $412.39 \pm 19.1$ & $3.04 \pm 0.05$ & $17.83 \pm 0.07$ \\
\hline Astaxanthin & $\begin{array}{c}63.15 \pm 6.25 \\
\left(\mathrm{IC}_{50}=7.22 \pm 0.02\right. \\
\mu \mathrm{g} / \mathrm{mL})\end{array}$ & $\begin{array}{c}585.73 \pm 13.22 \\
\left(\mathrm{IC}_{50}=89.47 \pm 0.08\right. \\
\mu \mathrm{g} / \mathrm{mL})\end{array}$ & $1045.56 \pm 13.43$ & $212.73 \pm 8.83$ & $923.45 \pm 20.3$ & - & - \\
\hline Galantamine & & & & & & $0.26 \pm 0.02$ & $3.82 \pm 0.02$ \\
\hline
\end{tabular}

${ }^{a}$ Antiradical DPPH activities are expressed as $\mu$ mol Trolox/g extract; ${ }^{b, c}$ expressed as $\mu$ mol Trolox/g extract; ${ }^{d}$ total phenolic content (TPC) expressed as $\mu \mathrm{mol}$ Trolox/g dry weight; ${ }^{\mathrm{a}}$ total carotenoid content (TCC) expressed as $\mu \mathrm{g}$ astaxanthin/g dry weight. ${ }^{\mathrm{f}} \mathrm{CHe}$ enzyme e inhibitory activity in $\mathrm{IC}_{50}$ in $\mu \mathrm{g} / \mathrm{mL}$. Values in the same column marked with the same letter are not significantly different (at $p<0.05$ ).

Pigment carotenoids were also detected with HPLC coupled to a photodiode array detector at $490 \mathrm{~nm}$ wavelength (Figure 3), and the main bacterioruberin carotenoid is in Halorubrum tebenquichense Te Se-86 (445.0 $\pm 6.24 \mu \mathrm{g} / \mathrm{g}$ dry cells, Table 3$)$ which also showed the higher content of total geometrical carotenoids $(871.53 \mu \mathrm{g} / \mathrm{g}$ dry cells $)$ measured by UHPLC. However, in terms of percentage regarding total carotenoids, bacterioruberin was higher in Haloarcula sp., TeSe-89 (59.5\% of the total carotenoids measured by UHPLC) close to TeSe-51 (59.1\%) then Haloarcula sp. TeSe-41 (58.2\%), then Halorubrum tebenquichense Te Se-85 (54.6\%) close to Halorubrum tebenquichense Te Se-86 (51.8\%), followed by Haloarcula sp. ALT-23 (51.4\%). Bacterioruberin contents in strain SGH1 from similar locations in Chile gave $427 \pm 8.72 \mu \mathrm{g} / \mathrm{g}, \% \mathrm{w} / \mathrm{v} \mathrm{NaCl}$ at $25^{\circ} \mathrm{C}$ [14]. However, lower carotenoid contents have been reported for other halophilic archaea; e.g., $75 \mu \mathrm{g} / \mathrm{g}$ of dry biomass in Haloterrigena turkmenica [45], $335 \mu \mathrm{g} / \mathrm{g}$ of dry biomass in Haloarcula japonica [46] and $45 \mu \mathrm{g} / \mathrm{g}$ of dry biomass in Halococcus morrhuae [12]. A bacterioruberin content of $1055.35 \mu \mathrm{g} / \mathrm{g}$ and total carotenoids of $2060 \mu \mathrm{g} / \mathrm{g}$ was reported in Haloferax alexandrinus, representing $51 \%$ of the total carotenoids [47], and also a huge bacterioruberin content (220 mg/g dry weight) was reported in a genetically modified Haloferax volcanii strain HVLON3, which also has higher antioxidant activity than standard $\beta$-carotene [16]. The application of enzyme inhibition medicines is considered effective to control several degenerative diseases, such as Alzheimer's disease, arthritis, and arthrosis. In this study, an in vitro inhibitory effect of the dried extract (dissolved in water) of several haloarchaea, on acetylcholinesterase and butyrilcholinesterase enzymes was investigated. The results of inhibitory potencies of choline esterase inhibitors (AChE and BuChE) inhibitory activities are shown in Table 3 and expressed as $\mathrm{IC}_{50}$. In particular, AChE inhibition $\mathrm{IC}_{50}$ was $2.96 \pm 0.08 \mathrm{mg} \mathrm{mL}^{-1}$ and $\mathrm{BuChE}$ inhibition $\mathrm{IC}_{50}$ was $2.39 \pm 0.09 \mathrm{mg} \mathrm{mL}^{-1}$ for the most active strain, Te Se-85, respectively, (Table 2), which is more active in $\mathrm{BuChE}$ than that of the standard galantamine (Table 2). This is in accordance with previous results of the inhibition of these enzymes on other investigated extremophile strains (but only reported in percentage, with a maximum $40 \%$ inhibition for the AChE enzyme for the strains Haloarcula hispanica and Halobacterium salinarum for chloroform and ethyl acetate extracts of the strains) [33]. 
Table 3. Total bacterioruberin carotenoids in haloarchaea: Te Se-85, Te Se-86, ALT-23, TeSe-41, TeSe-51 and TeSe-89 by UHPLC analyses.

\begin{tabular}{|c|c|c|c|c|c|c|}
\hline \multirow{2}{*}{ Strain } & \multicolumn{6}{|c|}{ Haloarchaea Content (mg/g Dry Biomass) } \\
\hline & Te Se-85 & Te Se-86 & ALT-23 & TeSe-41 & TeSe-51 & TeSe-89 \\
\hline Total carotenoids* & 600.06 & 871.53 & 488.88 & 536.93 & 532.89 & 508.412 \\
\hline Bacterioruberin & $328.9 \pm 3.23$ & $445.0 \pm 6.24$ & $251.52 \pm 4.22$ & $312.31 \pm 3.02$ & $315.92 \pm 3.13$ & $303.03 \pm 2.86$ \\
\hline 5-cis-Bacterioruberin & $27.84 \pm 1.45$ & $45.12 \pm 1.36$ & $18.87 \pm 0.98$ & $26.65 \pm 1.22$ & $25.13 \pm 1.06$ & $28.32 \pm 1.18$ \\
\hline 9-cis-Bacterioruberin & $52.43 \pm 1.86$ & $83.59 \pm 1.75$ & $41.36 \pm 1.22$ & $50.12 \pm 1.38$ & $46.44 \pm 1.32$ & $55.232 \pm 1.48$ \\
\hline 13-cis-Bacterioruberin & $56.98 \pm 0.98$ & $88.23 \pm 1.45$ & $49.26 \pm 0.65$ & $48.45 \pm 1.66$ & $54.87 \pm 1.22$ & $50.16 \pm 1.26$ \\
\hline 5-cis-26-cis-Bacterioruberin & $43.54 \pm 1.43$ & $76.44 \pm 1.95$ & $39.12 \pm 1.22$ & $32.66 \pm 1.75$ & $43.26 \pm 1.34$ & $37.76 \pm 1.08$ \\
\hline 9-cis-26-cis-Bacterioruberin & $22.35 \pm 0.96$ & $33.54 \pm 1.01$ & $21.87 \pm 0.56$ & $15.33 \pm 1.25$ & $20.14 \pm 1.12$ & $11.15 \pm 0.24$ \\
\hline Monoanhidrobacterioruberin & $9.22 \pm 0.54$ & $15.22 \pm 0.65$ & $9.21 \pm 0.46$ & $7.23 \pm 0.43$ & $6.32 \pm 0.35$ & $5.78 \pm 0.36$ \\
\hline $\begin{array}{l}\text { 5-cis- } \\
\text { monoanhidrobacterioruberin }\end{array}$ & $7.25 \pm 0.46$ & $12.26 \pm 0.57$ & $6.31 \pm 0.37$ & $5.32 \pm 0.32$ & $4.28 \pm 0.16$ & $3.66 \pm 0.26$ \\
\hline $\begin{array}{l}\text { Reduced } \\
\text { monoanhidrobacterioruberin }\end{array}$ & $5.12 \pm 0.21$ & $8.32 \pm 0.23$ & $5.12 \pm 0.21$ & $3.46 \pm 0.27$ & $2.38 \pm 0.21$ & $1.87 \pm 0.17$ \\
\hline $\begin{array}{l}\text { 9-cis- } \\
\text { Monoanhidrobacterioruberin }\end{array}$ & $6.34 \pm 0.31$ & $9.47 \pm 0.42$ & $5.32 \pm 0.16$ & $5.59 \pm 0.18$ & $1.98 \pm 0.17$ & $0.87 \pm 0.12$ \\
\hline $\begin{array}{l}\text { 13-cis- } \\
\text { Monoanhidrobacterioruberin }\end{array}$ & $6.28 \pm 0.28$ & $9.16 \pm 0.67$ & $4.39 \pm 0.19$ & $5.93 \pm 0.43$ & $2.25 \pm 0.15$ & $0.69 \pm 0.17$ \\
\hline Reduced & $7.32 \pm 0.25$ & $9.46 \pm 0.33$ & $5.26 \pm 0.23$ & $5.67 \pm 0.48$ & $1.83 \pm 0.03$ & $0.91 \pm 0.05$ \\
\hline Bisanhidrobacterioruberin & $5.03 \pm 0.11$ & $8.16 \pm 0.12$ & $5.26 \pm 0.22$ & $3.92 \pm 0.34$ & $1.78 \pm 0.31$ & $1.95 \pm 0.26$ \\
\hline $\begin{array}{l}5 \text {-cis- } \\
\text { bisanhidrobacterioruberin }\end{array}$ & $4.81 \pm 0.24$ & $7.42 \pm 0.15$ & $4.11 \pm 0.13$ & $2.55 \pm 0.23$ & $0.67 \pm 0.21$ & $0.73 \pm 0.12$ \\
\hline $\begin{array}{l}\text { 9-cis- } \\
\text { bisanhidrobacterioruberin }\end{array}$ & $7.23 \pm 0.34$ & $9.25 \pm 0.33$ & $9.45 \pm 0.45$ & $4.76 \pm 0.23$ & $2.23 \pm 0.45$ & $2.43 \pm 0.37$ \\
\hline $\begin{array}{l}\text { Reduced } \\
\text { Bisanhidrobacterioruberin }\end{array}$ & $9.42 \pm 0.45$ & $10.89 \pm 0.47$ & $12.45 \pm 0.74$ & $6.98 \pm 0.74$ & $3.41 \pm 0.36$ & $3.87 \pm 0.27$ \\
\hline
\end{tabular}

* Sum of individual carotenoids compounds.

\subsection{Effect of Biomass Haloarchaea in Skin Cell Line}

The use of carotenoid antioxidant components from extremophilic microorganisms has great potential in therapies for the human health; for this reason, we decided to test the extracts from a selected haloarchaea in a skin cell line called HaCaT. Initially, the metabolic activity associated with cell viability was evaluated by the MTT assay. Cell viability in the $\mathrm{HaCaT}$ cell line showed a significant decrease at $6 \mathrm{~h}$ post stimulus at a concentration of $1000,500,250,125,62.5 \mu \mathrm{g} / \mathrm{mL}$ (Figure 5). However, the same concentrations do not show differences after 24,48 and $72 \mathrm{~h}$. Although the concentration of $250 \mu \mathrm{g} / \mathrm{mL}$ showed a trend to increase the cell viability, in the concentration of $15 \mu \mathrm{g} / \mathrm{mL}$, a decrease in cell viability at 6 and $48 \mathrm{~h}$ was observed, while after 24 and $72 \mathrm{~h}$, no significative differences were observed after cell stimulation (Figure 5). These results suggest that biomass has an effect on cellular metabolism, being able to affect the correct cellular functioning. This capacity would allow us to decrease the metabolism in cells with a high proliferation rate, such as cancer. This is what has been observed in other studies, where the use of supernatant metabolites reduces the proliferative rate of these cells, reducing the size of the tumor [48]. Moreover, the anti-cancer effect of supernatant metabolites from Halobacterium salinarum was published. Apoptosis was induced by overexpression of CASP3, by a reduction in pluripotency through the downregulation of SOX2 and causing the eradication of tumors in a mouse model [48]. For the same reason, to elucidate whether haloarchaea biomass influences the activation of pathways related to oxidative stress, we decided to evaluate the concentration of nitrites in the culture supernatants at 15 and $125 \mu \mathrm{g} / \mathrm{mL}$ at 24 and $48 \mathrm{~h}$ using Griess assays (Figure 6), because in the case of a possible future use, it should be tested in small concentrations. Our results do not show a significant difference in $\mathrm{HaCaT}$ stimulation compared to the control, showing that strain biomass does not stimulate the $\mathrm{HaCaT}$ cells to modify the oxidative stress response, suggesting that the decrease in viability may be due to a different mechanism. However, to understand the effect of biomass on cell repair or the inhibition of any signaling pathway, it is necessary to use in vitro or in vivo models of inflammation and cell damage [48]. 


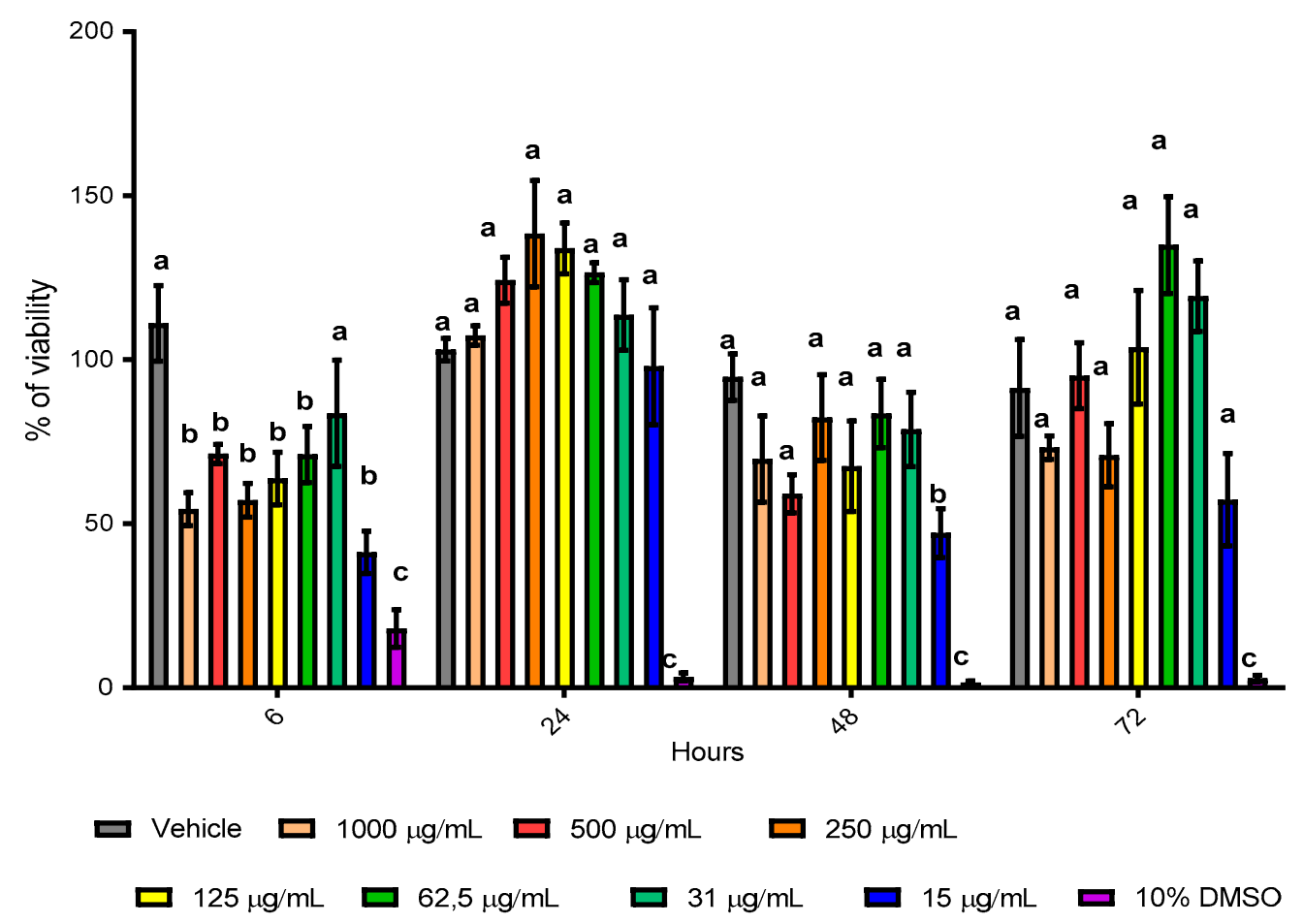

Figure 5. Effect of biomass in HaCaT skin cell line evaluated by MTT assay. The figure shows $\mathrm{HaCaT}$ cells cultivated with biomass of the strains Halorubrum tebenquichense Te Se-86 for 6, 24, 48 and $72 \mathrm{~h}$ of stimulus. The stimulus was evaluated as a percentage of viability with respect to the vehicle. Serial dilutions from 1000 to $15 \mu \mathrm{g} / \mathrm{mL}$ were incubated. Three independent experiments were performed. Bars indicate mean $\pm \mathrm{SD}$. Equal letters are not significative differences; different letters show a significative difference. $p<0.05$, using a Kruskal-Wallis statistics test.
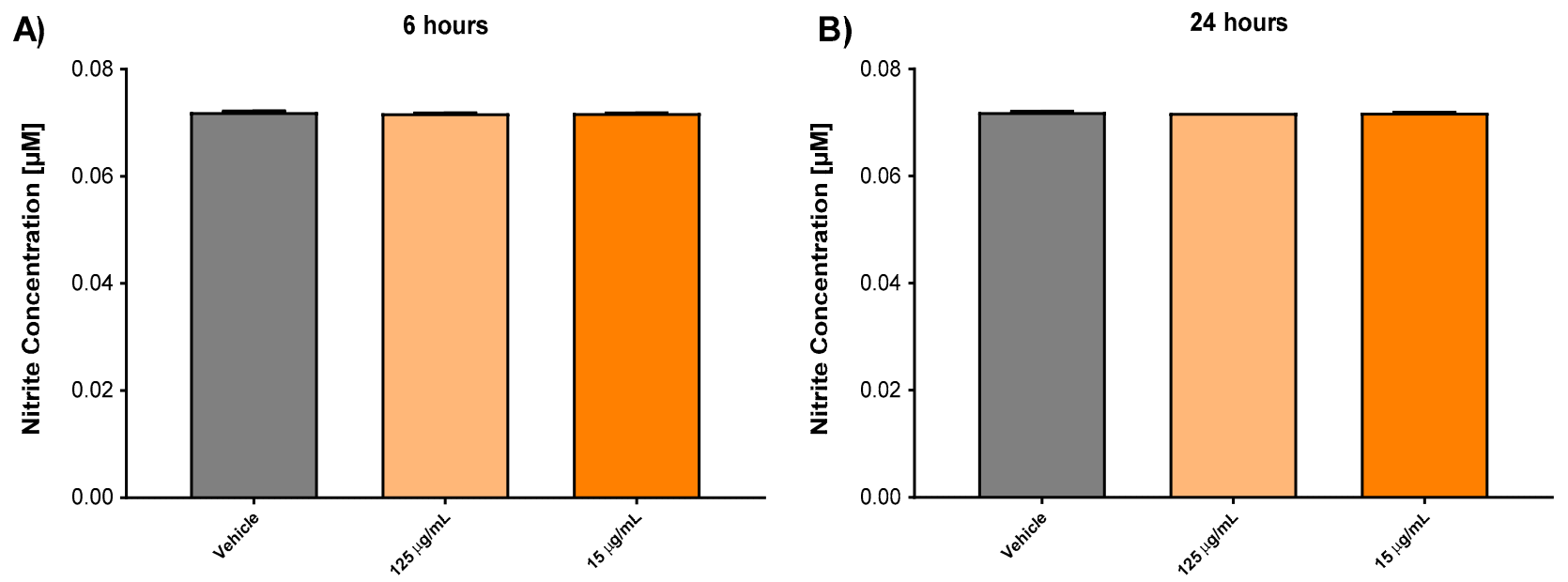

Figure 6. Effect of haloarchaea biomass on the secretion of nitrites in HaCaT skin cell line. The figure shows HaCaT cells cultivated with biomass of the strains Halorubrum tebenquichense Te Se-86 for 6 and $24 \mathrm{~h}$ of stimulus. The secretion of nitrites was evaluated by Griess assay, quantified as a concentration calculated in $\mu \mathrm{M}$. (A) Nitrite concentration after $6 \mathrm{~h}$ of stimulus. (B) Nitrite concentration after $24 \mathrm{~h}$ of stimulus. Bars indicate mean $\pm \mathrm{SD}, p<0.05$, using a Kruskal-Wallis statistics test.

\subsection{Docking Assays of Carotenoids in Haloarchaea Species}

Docking simulations were carried for each carotenoid fragment shown in Figures 7 and 8 obtained from haloarchaea species. Figure 7 shows the fragmentation pattern of each carotenoid structure and Figure 8 summarizes the fragments used in cholinesterase docking assays. 

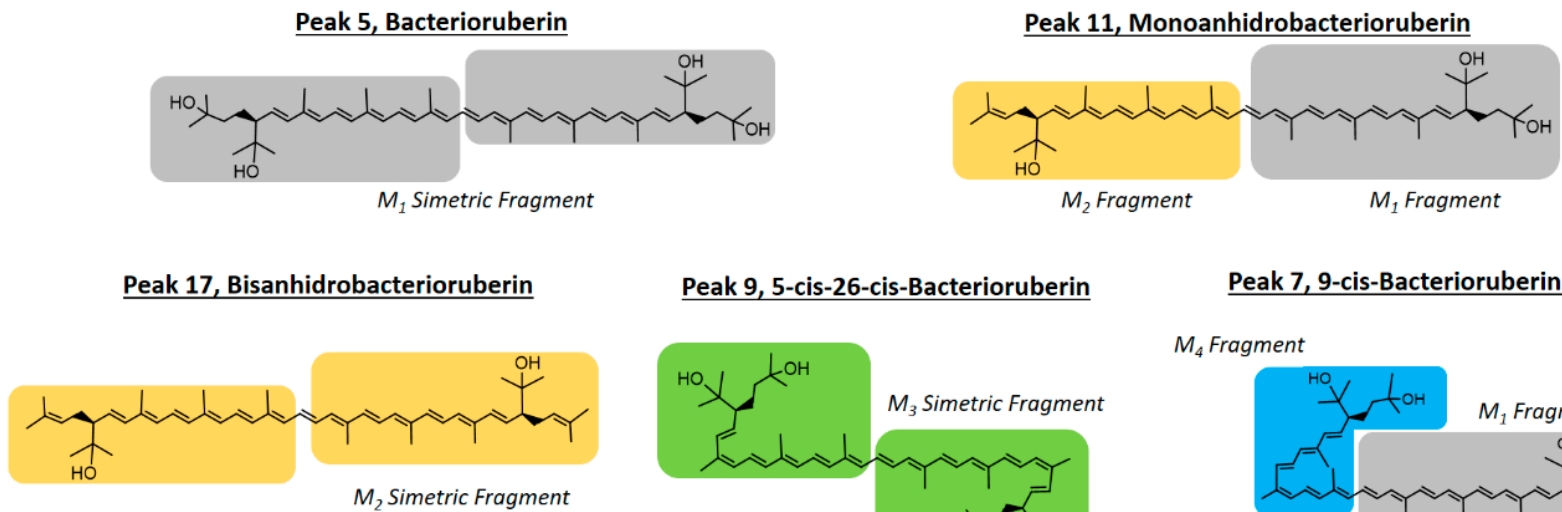

Peak 9, 5-cis-26-cis-Bacterioruberin

Peak 7, 9-cis-Bacterioruberin

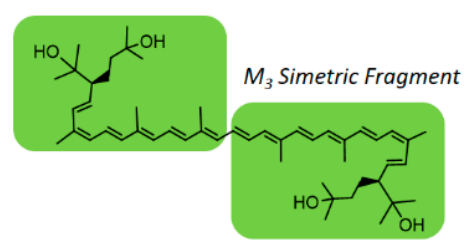

$M_{4}$ Fragment

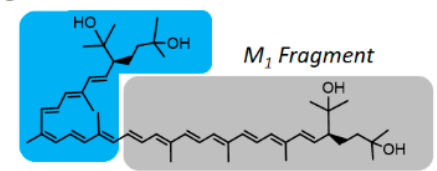

Peak 8, 13-cis-Bacterioruberin

Peak 10, 9-cis-26-cis-Bacterioruberin
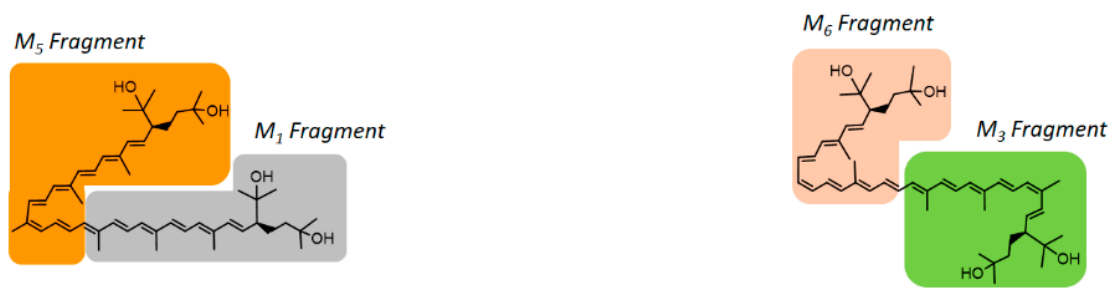

Figure 7. Carotenoids structures found in haloarchaea species and colored fragments tested in docking assays.

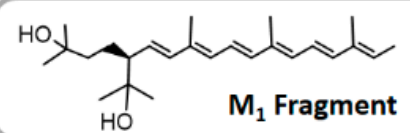
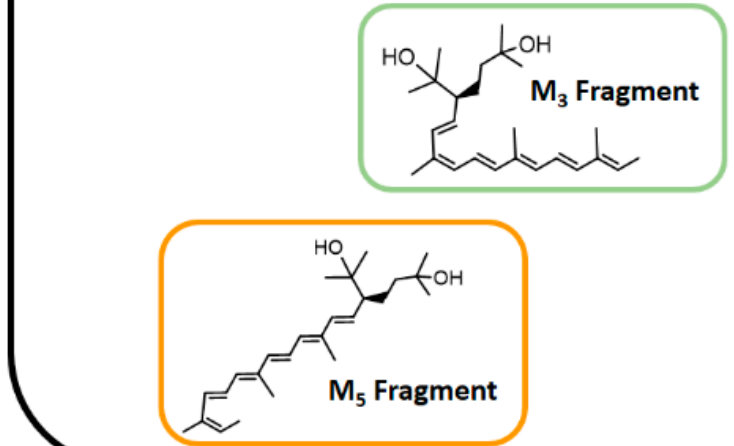
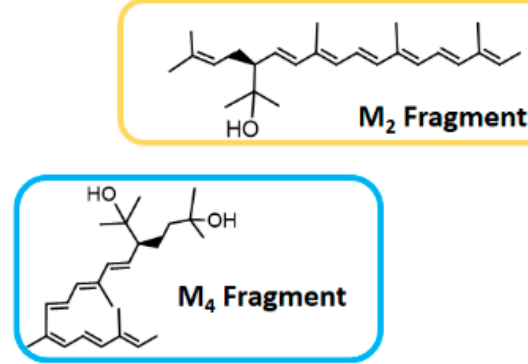

$\mathrm{M}_{4}$ Fragment

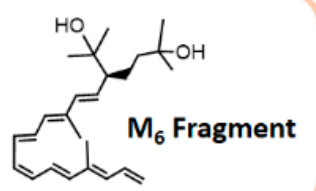

Figure 8. Carotenoids structure fragments used in cholinesterase docking assays.

\subsubsection{Acetylcholinesterase Docking Results}

The acetylcholinesterase enzyme corresponds to a homodimer bound to the plasma membrane through covalently attached phosphatidylinositol. The monomer is an $\alpha / \beta$ protein with an ellipsoidal shape. Likewise, acetylcholinesterase catalytic site has been well established, consisting of a narrow gorge, about $20 \AA$ long, and reaches halfway into the protein and widens out close to its bottom. The amino acids involved in the catalytic activity (known as the catalytic triad) are Ser200, Glu327 and His440, but also a hydrophobic pocket exists, where 14 residues such as Trp84, Tyr121, Trp279, Phe288, Phe290, Phe330, Phe331, Tyr334, among others, in a substantial portion of the surface of the gorge. Taking into account the above information and considering that all carotenoids shown in Figure 4 correspond to aliphatic chains of at least 50 carbon atoms, that is to say long hydrocarbon 
chains (30 ̊ length on average), they would not fit well into the acetylcholinesterase catalytic site. The latter suggest that carotenoids exert their inhibitory activity fitting into the enzyme pocket by their halves, one located half out of the catalytic site and the other performing the biological activity, or both halves can exert inhibitory activities in the case that they are in the presence of cholinesterase dimers. In this manner, we decided to fragment the carotenoid structures, since most of them show a plane of symmetry or the fragmented portions are equivalent (e.g., bacterioruberin halves-fragments are equivalent to one fragment of those exhibited by monoanhidrobacterioruberin, Figure 7).

The geometries and partial charges of every fragment were fully optimized using the semi-empirical method for quantum calculation Austin Model 1 (AM1) [49] in Gaussian 09W software [40]. Crystallographic enzyme structures of Torpedo californica acetylcholinesterase (TcAChE; PDBID: 1DX6 code [50]) and human butyrylcholinesterase ( $h$ BuChE; PDBID: 4BDS code [51]) were downloaded from the Protein Data Bank RCSB PDB [52]. Docking experiments were performed using Autodock 4.2 [53], and consequently grid maps were calculated using the autogrid option and were centered on the putative catalytic site of each enzyme, considering their known catalytic amino acids: Ser200 for acetylcholinesterase (TcAChE) $[54,55]$ and Ser198 for butyrylcholinesterase $(h \mathrm{BuChE})[56,57]$, respectively. The volumes chosen for the grid maps were made up of $60 \times 60 \times 60$ points, with a grid-point spacing of $0.375 \AA$. Docked compound complexes were built using the Lamarckian genetic algorithm [58], which involved 100 runs. The lowest docked-energy binding cluster positions were chosen to be analyzed according to the potential intermolecular interactions between inhibitors and the enzymes. The different complexes were displayed in a visual molecular dynamics program (VMD) and Pymol [59].

Butyrylcholinesterase belongs to the same structural class of proteins as acetylcholinesterase, belonging to the esterase/lipase family, and being a serine hydrolase as well $[60,61]$. The butyrylcholinesterase catalytic triad is composed of Ser198, Glu325 and His438. The catalytic site, such as acetylcholinesterase, is located at the bottom of a deep and narrow gorge of the enzyme. One of the main differences between butyrylcholinesterase and acetylcholinesterase are some residues lining the gorge, where the former enzyme has replaced several of the aromatic groups of the latter by hydrophobic ones [62]. In view of the information already mentioned, we also decided to use the carotenoid halves main fragments depicted in Figure 8 to perform docking assays over butyrylcholinesterase.

Table 4 shows the best docking binding energies expressed in $\mathrm{kcal} / \mathrm{mol}$ of each carotenoid fragments $\left(\mathrm{M}_{1}, \mathrm{M}_{2}, \mathrm{M}_{3}, \mathrm{M}_{4}, \mathrm{M}_{5}\right.$ and $\left.\mathrm{M}_{6}\right)$ obtained from haloarchaea species, as well as the known cholinesterase inhibitor galantamine. Docking results would allow us to rationalize the carotenoid inhibitory properties through the analysis of the proteins molecular interactions in the light of the obtained results shown in Table 2.

Table 4. Binding energies obtained from docking experiments of carotenoids in haloarchaea species over acetylcholinesterase and butyrylcholinesterase.

\begin{tabular}{ccc}
\hline Compound & $\begin{array}{c}\text { Binding Energy (kcal/mol) } \\
\text { Acetylcholinesterase }\end{array}$ & $\begin{array}{c}\text { Binding Energy (kcal/mol) } \\
\text { Butyrylcholinesterase }\end{array}$ \\
\hline Fragment $\mathrm{M}_{1}$ & -9.74 & -7.42 \\
Fragment $\mathrm{M}_{2}$ & -10.15 & -7.89 \\
Fragment $\mathrm{M}_{3}$ & -10.35 & -8.35 \\
Fragment $\mathrm{M}_{4}$ & -9.53 & -9.40 \\
Fragment $\mathrm{M}_{5}$ & -8.50 & -8.62 \\
Fragment $\mathrm{M}_{6}$ & -9.54 & -9.90 \\
Galantamine & -11.81 & -9.50 \\
\hline
\end{tabular}

All fragments displayed several hydrophobic interactions in the acetylcholinesterase catalytic site, specifically with the hydrophobic residues at the surface of the catalytic gorge, which probably represents the main components of their inhibitory activities. In addition, the hydroxyl groups located in the fragments demonstrated to produce hydrogen 
bond interactions with amino acids Trp82, Tyr121, Gly117, Ser122 and Glu199 as well (Figure 9A-F).
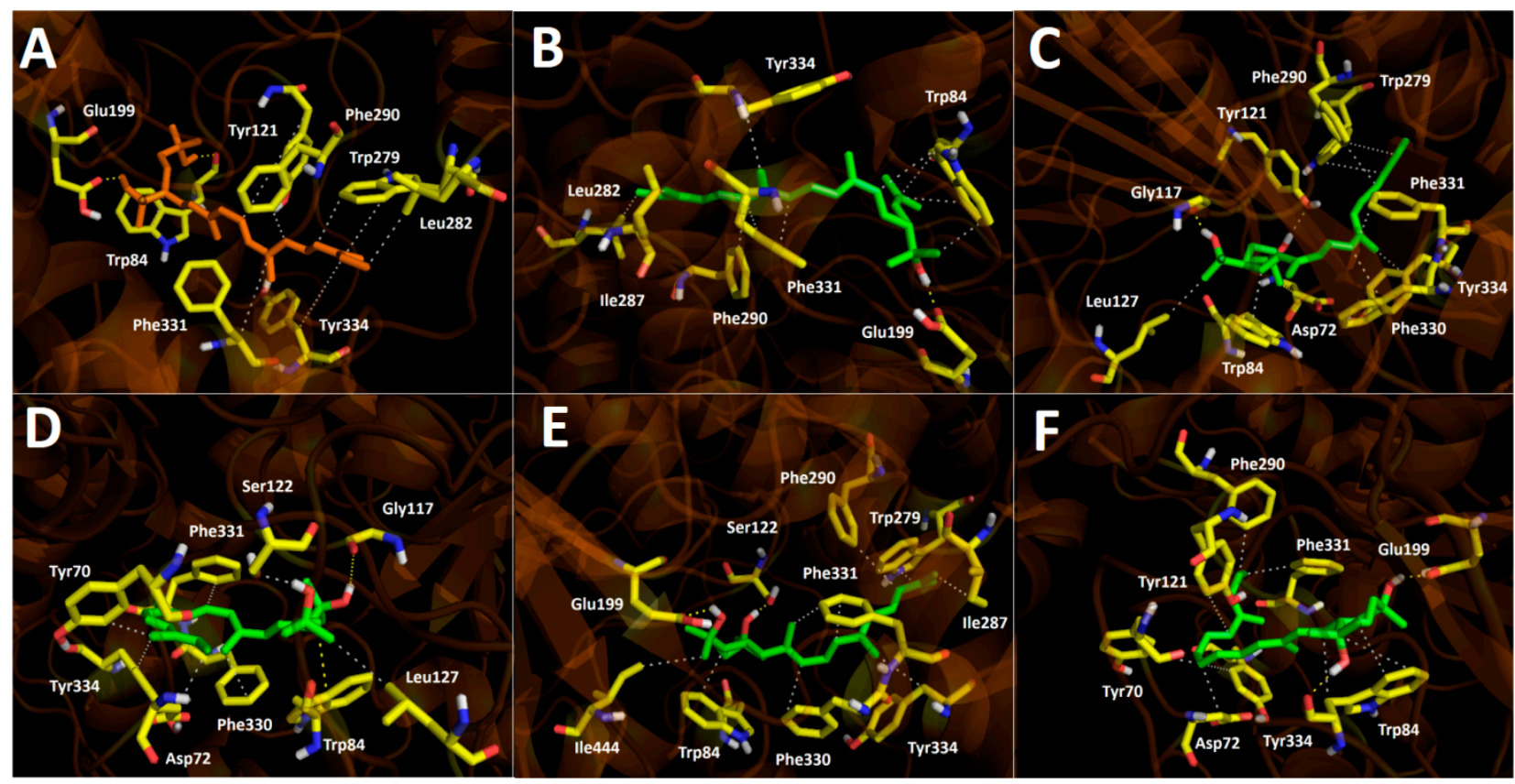

Figure 9. Predicted binding mode and predicted intermolecular interactions of different fragments (Figure 8) in the catalytic site of acetylcholinesterase; (A) fragment $M_{1}$ in the catalytic site (B) fragment $M_{2}$ in the catalytic site; $(C)$ fragment $M_{3}$ in the catalytic site; (D) fragment $\mathrm{M}_{4}$ in the catalytic site; (E) fragment $\mathrm{M}_{5}$ in the catalytic site; (F) fragment $\mathrm{M}_{6}$ in the catalytic site.

Fragment $\mathrm{M}_{1}$, which constitutes part of the structures of bacterioruberin, monoanhidrobacterioruberin, 9-cis-bacterioruberin and 13-cis-bacterioruberin, exhibited a binding energy value of $-9.74 \mathrm{kcal} / \mathrm{mol}$. Fragment $\mathrm{M}_{5}$ showed the worst binding energy and is present only in 13-cis-bacterioruberin structure. Additionally, 13-cis-bacterioruberin contains fragment $\mathrm{M}_{1}$, which, as can be seen in Table 4, did not possess the best binding energy value. Thus, it is probable that 13-cis-bacterioruberin would not be the most potent carotenoid as an acetylcholinesterase inhibitor.

Fragment $\mathrm{M}_{2}$, contained in monoanhidrobacterioruberin and bisanhidrobacterioruberin, showed a good binding energy and one hydrogen bond interaction and plenty of hydrophobic interactions with amino acid residues, including Trp 84, Leu282, Ile287 and Phe 290, among others. This suggests that both carotenoids mentioned above would behave as acetylcholinesterase inhibitors as well; nonetheless, as bisanhidrobacterioruberin corresponds to a symmetric structure containing two portions of fragment $\mathrm{M}_{2}$, it is possible that this derivative would demonstrate a better inhibitory profile over the enzyme.

Fragment $\mathrm{M}_{3}$ displayed the best binding energy, and it is the only fragment that arranges in a different manner into the acetylcholinesterase catalytic pocket projecting its hydroxyl groups toward a different direction, performing hydrogen bond interactions with the residues Tyr121 and Gly117 (Figure 9C). The different fitting of fragment $\mathrm{M}_{3}$ related to the other derivatives could be attributed to the cis double bond near to the branched chains that bear the hydroxyl groups. Fragment $\mathrm{M}_{3}$ can be found exclusively in the symmetrical 5-cis-26-cis-bacterioruberin carotenoid, which suggests that this derivative could exhibit the highest potency feature compared to other carotenoids. 9-cis-26-cis-bacterioruberin bears fragment $\mathrm{M}_{3}$ as well, but also contains fragment $\mathrm{M}_{6}$ in its structure, which raises the possibility that both fragments of 9-cis-26-cis-bacterioruberin could exert the inhibitory activity in the acetylcholinesterase catalytic site, competing between each other. What is mentioned above could harm the inhibitory profile of this derivative, considering that fragment $\mathrm{M}_{6}$ presented a binding energy of $-9.54 \mathrm{kcal} / \mathrm{mol}$, lower than fragment $\mathrm{M}_{3}$ and 
similar to fragment $\mathrm{M}_{4}$, since the former fragment $\left(\mathrm{M}_{6}\right)$ only differs in a methyl group from the latter fragment $\left(\mathrm{M}_{4}\right)$ in their structures (Figure 8).

In view of docking results, the best carotenoid fragment turned out to be fragment $\mathrm{M}_{3}$, and the worst fragment was $\mathrm{M}_{5}$, which is only borne by the 13-cis-bacterioruberin derivative. Nonetheless, all of them showed a similar manner of being arranged into the catalytic site, and hydrophobic interactions were shown to be an important non-competitive intermolecular binding docking descriptor.

\subsubsection{Butyrylcholinesterase Docking Results}

Binding energies from docking assays over butyrylcholinesterase of fragments $M_{1}$, $\mathrm{M}_{2}, \mathrm{M}_{3}, \mathrm{M}_{4}, \mathrm{M}_{5}$ and $\mathrm{M}_{6}$ showed a similar behavior pattern in terms of binding energies regarding those shown by acetylcholinesterase. No substantial differences among themselves or in comparison with the known inhibitor galantamine were found. These features can be corroborated through the comparison of the half-maximal inhibitory concentrations $\left(\mathrm{IC}_{50}\right)$ presented by the six different haloarchaea obtained from the II region of Chile (Table 2).

As in acetylcholinesterase docking assays, hydrophobic interactions also predominated in all fragments, with the residues Trp82, Gln 119, Phe 329, Trp430, among others, being implicated (Figure 10A-F). All fragments were arranged into the butyrylcholinesterase catalytic site in a similar manner, except for fragment $\mathrm{M}_{3}$ again, probably due to its cis double bond near to the branched chains that bear the hydroxyl groups, projecting them in different directions and leading to the obtention of hydrogen bond interactions with amino acids Glu197 and Thr120 (Figure 10C).
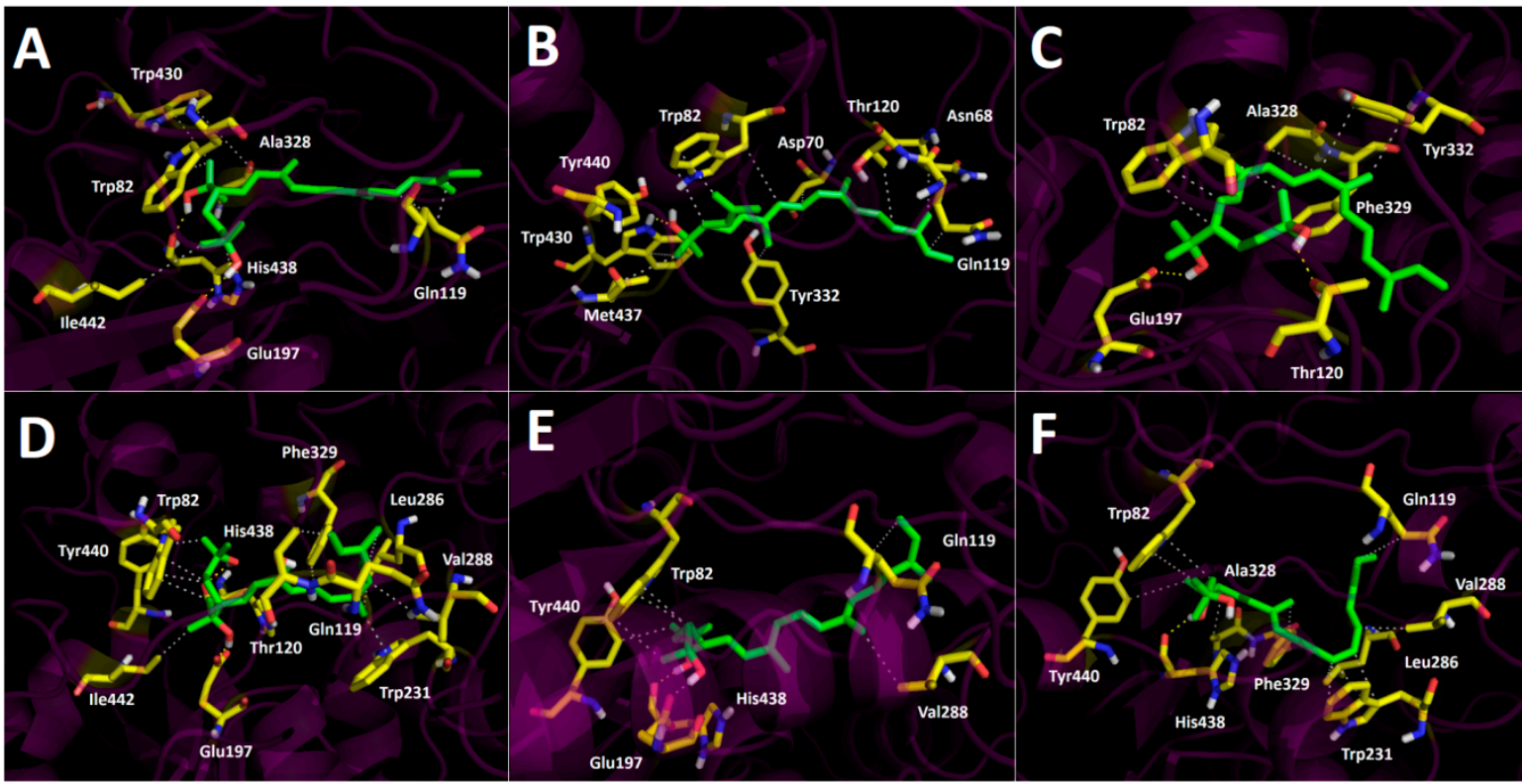

Figure 10. Predicted binding mode and predicted intermolecular interactions of different fragments (Figure 8) in the catalytic site of butyrylcholinestesase; (A) fragment $M_{1}$ in the catalytic site; (B) fragment $M_{2}$ in the catalytic site; (C) fragment $M_{3}$ in the catalytic site; (D) fragment $M_{4}$ in the catalytic site; (E) fragment $M_{5}$ in the catalytic site; (F) fragment $M_{6}$ in the catalytic site.

Fragment $\mathrm{M}_{1}$ showed the lowest binding energy profile, suggesting that all carotenoids which bear this fragment, such as bacterioruberin, monoanhidrobacterioruberin, 9-cisbacterioruberin and 13-cis-bacterioruberin could mainly exert their inhibitory activities through the other fragment that each of them also possesses, except carotenoid bacterioruberin, since it is a symmetrical molecule bearing two fragment $\mathrm{M}_{1}$ portions.

9-cis-bacterioruberin represents a special case, due to it being sectionated in two different fragments (fragment $\mathrm{M}_{1}$ and fragment $\mathrm{M}_{4}$ ). Since, 9-cis-bacterioruberin bears fragment $\mathrm{M}_{4}$, it is possible that if an isolated inhibition assay over butyrylcholinesterase 
of this derivative were performed, the main activity could be attributed to fragment $\mathrm{M}_{4}$ instead of fragment $\mathrm{M}_{1}$, considering the high binding energy of $-9.40 \mathrm{kcal} / \mathrm{mol}$ exhibited by this fragment, and hence a better binding affinity of it. Something similar happens with derivative 13-cis-bacterioruberin sectionated in fragment $\mathrm{M}_{1}$ and fragment $\mathrm{M}_{5}$ (Figure 7), where the whole inhibitory activity could fall over fragment $\mathrm{M}_{5}$.

Monoanhidrobacterioruberin possesses in its structure fragment $\mathrm{M}_{1}$ and fragment $\mathrm{M}_{2}$. However, both fragments demonstrated low binding energies, it which suggests that this carotenoid would not behave as the most potent inhibitor. On the other hand, bisanhidrobacterioruberin is a symmetrical compound bearing fragment $\mathrm{M}_{2}$ twice, but as in monoanhidrobacterioruberin, fragment $\mathrm{M}_{2}$ also exhibits a low binding energy profile.

Fragment $\mathrm{M}_{6}$ showed the best binding energy $(-9.90 \mathrm{kcal} / \mathrm{mol})$, and the only carotenoid that contains this fragment corresponds to 9-cis-26-cis-bacterioruberin. However, 9-cis-26cis-bacterioruberin also possesses fragment $\mathrm{M}_{3}$ (Figure 7), due the ability of the former fragment to fit into the butyrylcholinesterase catalytic site, turning this derivative into a good candidate to become a potent butyrylcholinesterase inhibitor.

\section{Conclusions}

Six haloarchaea strains from the extreme environment of the Atacama Desert were identified, namely Halorubrum tebenquichense Te Se-85, Halorubrum tebenquichense Te Se86, Haloarcula sp. ALT-23, Haloarcula sp. TeSe-41, Haloarcula sp. TeSe-51 and Haloarcula sp. TeSe-89. Antioxidant and cholinesterase enzymes inhibitory capacities supported by docking experiments plus carotene content were measured, and the presence of sixteen geometric bacterioruberin carotenoids was identified in the six haloarchaea. The compounds were identified by ultrahigh resolution liquid chromatography orbitrap MS analysis (UHPLC-PDA-OT-MS), and are reported for the first time, updating the knowledge on the chemical profile of these species. The effect of biomass on cellular viability in skin cell lines was also evaluated by MTT assay. More scientific data on bioactivity and chemistry are shown for these extremophiles that increase their potential for sustainable applications and industrial purposes. These valuable natural products biomass has great potential applications in food, medicine, biotechnology, pharmaceuticals, and cosmetics, with many possible applications from food coloring agents to anticancer biomaterials.

Supplementary Materials: The following are available online at: https:/ / www.mdpi.com/article/ 10.3390/antiox10081230/s1. Figure S1: UV visible spectra of bacterioruberins from haloarchaea. Figures S2 and S3: Full orbitrap MS spectra and structures of some representative compounds. Register of the $16 \mathrm{~S}$ rRNA gene sequences.

Author Contributions: M.J.S. and C.L. conceived and designed the experiments; C.L. performed haloarchaeas strains characterization, J.B., D.A., and F.R. performed the antioxidant, carotene, and total phenolic content experiments; J.R.-P. performed docking calculations and explained the results, M.J.S., S.A. and J.B. analyzed the data of HPLC/MS. L.V.-S. and C.C. performed the analyzed to Effect of biomass in skin cell line. All authors have read and agreed to the published version of the manuscript.

Funding: Mario Simirgiotis and Jorge Bórquez received financial support from Fondecyt, Chile (Grant 1180059); Catherine Lizama and Daniel Andrade from VIU18E0145 and Network for Extreme Environments Research Project (NEXER Project (ANT1756), Universidad de Antofagasta, Chile; Luis Venegas received financial support from postdoctoral Fondecyt 3180572 and Shakeel Ahmed from Fondecyt Postdoctorado 3190572.

Institutional Review Board Statement: Not applicable.

Informed Consent Statement: Not applicable.

Data Availability Statement: The data presented in this study are available in the article and its Supplementary Materials.

Conflicts of Interest: The authors do not have any conflict of interest. 


\section{References}

1. Lizama, C.; Monteoliva-Sánchez, M.; Prado, B.; Ramos-Cormenzana, A.; Weckesser, J.; Campos, V. Taxonomic study of extreme halophilic archaea isolated from the "Salar de Atacama", Chile. Syst. Appl. Microbiol. 2001, 24, 464-474. [CrossRef]

2. Farias, M.E.; Rasuk, M.C.; Gallagher, K.L.; Contreras, M.; Kurth, D.; Fernandez, A.B.; Poiré, D.; Novoa, F.; Visscher, P.T. Prokaryotic diversity and biogeochemical characteristics of benthic microbial ecosystems at La Brava, a hypersaline lake at Salar de Atacama, Chile. PLoS ONE 2017, 12, e0186867. [CrossRef]

3. Zhang, J.; Sun, Z.; Sun, P.; Chen, T.; Chen, F. Microalgal carotenoids: Beneficial effects and potential in human health. Food Funct. 2014, 5, 413-425. [CrossRef]

4. Vílchez, C.; Forján, E.; Cuaresma, M.; Bédmar, F.; Garbayo, I.; Vega, J.M. Marine carotenoids: Biological functions and commercial applications. Mar. Drugs 2011, 9, 319-333. [CrossRef]

5. Sun, T.; Yuan, H.; Cao, H.; Yazdani, M.; Tadmor, Y.; Li, L. Carotenoid Metabolism in Plants: The Role of Plastids. Mol. Plant 2018, 11, 58-74. [CrossRef] [PubMed]

6. Yatsunami, R.; Ando, A.; Yang, Y.; Takaichi, S.; Kohno, M.; Matsumura, Y.; Ikeda, H.; Fukui, T.; Nakasone, K.; Fujita, N.; et al. Identification of carotenoids from the extremely halophilic archaeon Haloarcula japonica. Front. Microbiol. 2014, 5. [CrossRef]

7. Mata-Gómez, L.C.; Montañez, J.C.; Méndez-Zavala, A.; Aguilar, C.N. Biotechnological production of carotenoids by yeasts: An overview. Microb. Cell Fact. 2014, 13, 1-11. [CrossRef]

8. Dufossé, L.; Fouillaud, M.; Caro, Y.; Mapari, S.A.S.; Sutthiwong, N. Filamentous fungi are large-scale producers of pigments and colorants for the food industry. Curr. Opin. Biotechnol. 2014, 26, 56-61. [CrossRef]

9. Calegari-Santos, R.; Diogo, R.A.; Fontana, J.D.; Bonfim, T.M.B. Carotenoid Production by Halophilic Archaea under Different Culture Conditions. Curr. Microbiol. 2016, 72, 641-651. [CrossRef] [PubMed]

10. Jehlička, J.; Edwards, H.G.M.; Oren, A. Bacterioruberin and salinixanthin carotenoids of extremely halophilic Archaea and Bacteria: A Raman spectroscopic study. Spectrochim. Acta Part A Mol. Biomol. Spectrosc. 2013, 106, 99-103. [CrossRef] [PubMed]

11. Naziri, D.; Hamidi, M.; Hassanzadeh, S.; Tarhriz, V.; Zanjani, B.M.; Nazemyieh, H.; Hejazi, M.A.; Hejazi, M.S. Analysis of carotenoid production by Halorubrum sp. TBZ126; an extremely halophilic archeon from Urmia Lake. Adv. Pharm. Bull. 2014, 4, 61-67. [CrossRef] [PubMed]

12. Mandelli, F.; Miranda, V.S.; Rodrigues, E.; Mercadante, A.Z. Identification of carotenoids with high antioxidant capacity produced by extremophile microorganisms. World J. Microbiol. Biotechnol. 2012, 28, 1781-1790. [CrossRef]

13. De la Vega, M.; Sayago, A.; Ariza, J.; Barneto, A.G.; León, R. Characterization of a bacterioruberin-producing Haloarchaea isolated from the marshlands of the Odiel river in the southwest of Spain. Biotechnol. Prog. 2016, 32, 592-600. [CrossRef]

14. Flores, N.; Hoyos, S.; Venegas, M.; Galetović, A.; Zúñiga, L.M.; Fábrega, F.; Paredes, B.; Salazar-Ardiles, C.; Vilo, C.; Ascaso, C.; et al. Haloterrigena sp. Strain SGH1, a Bacterioruberin-Rich, Perchlorate-Tolerant Halophilic Archaeon Isolated From Halite Microbial Communities, Atacama Desert, Chile. Front. Microbiol. 2020, 11, 324. [CrossRef] [PubMed]

15. Abbes, M.; Baati, H.; Guermazi, S.; Messina, C.; Santulli, A.; Gharsallah, N.; Ammar, E. Biological properties of carotenoids extracted from Halobacterium halobium isolated from a Tunisian solar saltern. BMC Complement. Altern. Med. 2013, 13, 255. [CrossRef] [PubMed]

16. Zalazar, L.; Pagola, P.; Miró, M.V.; Churio, M.S.; Cerletti, M.; Martínez, C.; Iniesta-Cuerda, M.; Soler, A.J.; Cesari, A.; De Castro, R. Bacterioruberin extracts from a genetically modified hyperpigmented Haloferax volcanii strain: Antioxidant activity and bioactive properties on sperm cells. J. Appl. Microbiol. 2019, 126, 796-810. [CrossRef] [PubMed]

17. Fariq, A.; Yasmin, A.; Jamil, M. Production, characterization and antimicrobial activities of bio-pigments by Aquisalibacillus elongatus MB592, Salinicoccus sesuvii MB597, and Halomonas aquamarina MB598 isolated from Khewra Salt Range, Pakistan. Extremophiles 2019, 23, 435-449. [CrossRef]

18. Hou, J.; Cui, H.L. In Vitro Antioxidant, Antihemolytic, and Anticancer Activity of the Carotenoids from Halophilic Archaea. Curr. Microbiol. 2018, 75, 266-271. [CrossRef]

19. Hegazy, G.E.; Abu-Serie, M.M.; Abo-Elela, G.M.; Ghozlan, H.; Sabry, S.A.; Soliman, N.A.; Abdel-Fattah, Y.R. In vitro dual (anticancer and antiviral) activity of the carotenoids produced by haloalkaliphilic archaeon Natrialba sp. M6. Sci. Rep. 2020, 10, 1-14. [CrossRef]

20. Urdiain, M.; López-López, A.; Gonzalo, C.; Busse, H.J.; Langer, S.; Kämpfer, P.; Rosselló-Móra, R. Reclassification of Rhodobium marinum and Rhodobium pfennigii as Afifella marina gen. nov. comb. nov. and Afifella pfennigii comb. nov., a new genus of photoheterotrophic Alphaproteobacteria and emended descriptions of Rhodobium, Rhodobium orientis and Rhodobium gokarnense. Syst. Appl. Microbiol. 2008, 31, 339-351. [CrossRef]

21. Delong, E.F. Archaea in coastal marine environments (achabaterla/phyoey/batwe nt/n a eclogU). Proc. Natl. Acad. Sci. USA 1992, 89, 5685-5689. [CrossRef]

22. Weisburg, W.G.; Barns, S.M.; Pelletier, D.A.; Lane, D.J. 16 S ribosomal DNA amplification for phylogenetic study. J. Bacteriol. 1991, 173, 697-703. [CrossRef]

23. Stahl, A.D. Nucleic Acid Techniques in Bacterial Systematics. Dev. Appl. Nucleic Acid Probes 1991, 120, $205-248$.

24. Kumar, S.; Stecher, G.; Li, M.; Knyaz, C.; Tamura, K. MEGA X: Molecular evolutionary genetics analysis across computing platforms. Mol. Biol. Evol. 2018, 35, 1547-1549. [CrossRef]

25. Giani, M.; Martínez-Espinosa, R.M. Carotenoids as a Protection Mechanism against Oxidative Stress in Haloferax mediterranei. Antioxidants 2020, 9, 1060. [CrossRef] [PubMed] 
26. Simirgiotis, M.J.; Schmeda-Hirschmann, G.; Bórquez, J.; Kennelly, E.J. The Passiflora tripartita (banana passion) fruit: A source of bioactive flavonoid C-glycosides isolated by HSCCC and characterized by HPLC-DAD-ESI/MS/MS. Molecules 2013, 18, 1672. [CrossRef]

27. Brito, A.; Areche, C.; Sepúlveda, B.; Kennelly, E.J.; Simirgiotis, M.J. Anthocyanin characterization, total phenolic quantification and antioxidant features of some chilean edible berry extracts. Molecules 2014, 19, 936. [CrossRef] [PubMed]

28. Lichtenthaler, H.K.; Wellburn, A.R. Determinations of total carotenoids and chlorophylls a and b of leaf extracts in different solvents. Biochem. Soc. Trans. 1983, 11, 591-592. [CrossRef]

29. Aguilera, Á.; Suominen, S.; Pétursdóttir, S.; Olgudóttir, E.; Guðmundsdóttir, E.E.; Altamirano, M.; González-Toril, E.; Hreggviðsson, G.Ó. Physiological plasticity of high-temperature intertidal cyanobacterial microbial mats to temperature and salinity: Daily and seasonal in situ photosynthetic performance. Eur. J. Phycol. 2020, 55, 223-233. [CrossRef]

30. De Carvalho, L.M.J.; Gomes, P.B.; de Oliveira Godoy, R.L.; Pacheco, S.; do Monte, P.H.F.; de Carvalho, J.L.V.; Nutti, M.R.; Neves, A.C.L.; Vieira, A.C.R.A.; Ramos, S.R.R. Total carotenoid content, $\alpha$-carotene and $\beta$-carotene, of landrace pumpkins (Cucurbita moschata Duch): A preliminary study. Food Res. Int. 2012, 47, 337-340. [CrossRef]

31. Zeraik, M.L.; Queiroz, E.F.; Marcourt, L.; Ciclet, O.; Castro-Gamboa, I.; Silva, D.H.S.; Cuendet, M.; da Silva Bolzani, V.; Wolfender, J.-L. Antioxidants, quinone reductase inducers and acetylcholinesterase inhibitors from Spondias tuberosa fruits. J. Funct. Foods 2016, 21, 396-405. [CrossRef]

32. Barrientos, R.; Fernández-Galleguillos, C.; Pastene, E.; Simirgiotis, M.; Romero-Parra, J.; Ahmed, S.; Echeverría, J. Metabolomic Analysis, Fast Isolation of Phenolic Compounds, and Evaluation of Biological Activities of the Bark From Weinmannia trichosperma Cav. (Cunoniaceae). Front. Pharmacol. 2020, 11, 780. [CrossRef] [PubMed]

33. Gómez-Villegas, P.; Vigara, J.; Vila, M.; Varela, J.; Barreira, L.; Léon, R. Antioxidant, antimicrobial, and bioactive potential of two new haloarchaeal strains isolated from odiel salterns (Southwest Spain). Biology 2020, 9, 298. [CrossRef]

34. Kuskoski, E.M.; Asuero, A.G.; García-Parilla, M.C.; Troncoso, A.M.; Fett, R. Actividad antioxidante de pigmentos antociánicos. Ciênc. Tecnol. Aliment. 2004, 24, 691-693. [CrossRef]

35. Areche, C.; Hernandez, M.; Cano, T.; Ticona, J.; Cortes, C.; Simirgiotis, M.; Caceres, F.; Borquez, J.; Echeverría, J.; Sepulveda, B. Corryocactus brevistylus (K. Schum. ex Vaupel) Britton \& Rose (Cactaceae): Antioxidant, Gastroprotective Effects, and Metabolomic Profiling by Ultrahigh-Pressure Liquid Chromatography and Electrospray High Resolution Orbitrap Tandem Mass Spectrometry. Front. Pharmacol. 2020, 11, 417. [CrossRef] [PubMed]

36. Benzie, I.F.F.; Strain, J.J. The Ferric Reducing Ability of Plasma (FRAP) as a Measure of "Antioxidant Power": The FRAP Assay. Anal. Biochem. 1996, 239, 70-76. [CrossRef]

37. Mocan, A.; Zengin, G.; Simirgiotis, M.; Schafberg, M.; Mollica, A.; Vodnar, D.C.; Crişan, G.; Rohn, S. Functional constituents of wild and cultivated Goji (L. barbarum L.) leaves: Phytochemical characterization, biological profile, and computational studies. J. Enzyme Inhib. Med. Chem. 2017, 32, 153-168. [CrossRef]

38. Keerthi, S.; Koduru, U.D.; Nittala, S.S.; Parine, N.R. The heterotrophic eubacterial and archaeal co-inhabitants of the halophilic Dunaliella salina in solar salterns fed by Bay of Bengal along south eastern coast of India. Saudi J. Biol. Sci. 2018, 25, 1411-1419. [CrossRef]

39. Balasubramaniam, V.; June Chelyn, L.; Vimala, S.; Mohd Fairulnizal, M.N.; Brownlee, I.A.; Amin, I. Carotenoid composition and antioxidant potential of Eucheuma denticulatum, Sargassum polycystum and Caulerpa lentillifera. Heliyon 2020, 6, e04654. [CrossRef]

40. Frisch, A. Gaussian 09W Reference; Gaussian: Wallingford, UK, 2009.

41. BLAST: Basic Local Alignment Search Tool. Available online: https: / / blast.ncbi.nlm.nih.gov / Blast.cgi (accessed on 26 July 2021).

42. Nei, M.; Kumar, S. Molecular Evolution and Phylogenetics; Oxford University Press (OUP): Oxford, UK, 2000.

43. Sahli, K.; Gomri, M.A.; Esclapez, J.; Gómez-Villegas, P.; Ghennai, O.; Bonete, M.-J.; León, R.; Kharroub, K. Bioprospecting and characterization of pigmented halophilic archaeal strains from Algerian hypersaline environments with analysis of carotenoids produced by Halorubrum sp. BS2. J. Basic Microbiol. 2020, 60, 624-638. [CrossRef]

44. Rodrigo-Baños, M.; Garbayo, I.; Vílchez, C.; Bonete, M.J.; Martínez-Espinosa, R.M. Carotenoids from Haloarchaea and their potential in biotechnology. Mar. Drugs 2015, 13, 5508-5532. [CrossRef]

45. Squillaci, G.; Parrella, R.; Carbone, V.; Minasi, P.; La Cara, F.; Morana, A. Carotenoids from the extreme halophilic archaeon Haloterrigena turkmenica: Identification and antioxidant activity. Extremophiles 2017, 21, 933-945. [CrossRef]

46. Yang, Y.; Yatsunami, R.; Ando, A.; Miyoko, N.; Fukui, T.; Takaichi, S.; Nakamura, S. Complete biosynthetic pathway of the C50 carotenoid bacterioruberin from lycopene in the extremely halophilic archaeon Haloarcula japonica. J. Bacteriol. 2015, 197, 1614-1623. [CrossRef] [PubMed]

47. Asker, D.; Awad, T.; Ohta, Y. Lipids of Haloferax alexandrinus strain TMT: An extremely halophilic canthaxanthin-producing archaeon. J. Biosci. Bioeng. 2002, 93, 37-43. [CrossRef]

48. Safarpour, A.; Ebrahimi, M.; Fazeli, S.A.S.; Amoozegar, M.A. Supernatant metabolites from Halophilic Archaea to reduce tumorigenesis in prostate cancer in-vitro and in-vivo. Iran. J. Pharm. Res. 2019, 18, 241-253. [CrossRef] [PubMed]

49. Dewar, M.J.S.; Zoebisch, E.G.; Healy, E.F.; Stewart, J.J.P. AM1: A New General Purpose Quantum Mechanical Molecular Model1. J. Am. Chem. Soc. 1985, 107, 3902-3909. [CrossRef]

50. Greenblatt, H.M.; Kryger, G.; Lewis, T.; Silman, I.; Sussman, J.L. Structure of acetylcholinesterase complexed with (-)-galanthamine at $2.3 \AA$ resolution. FEBS Lett. 1999, 463, 321-326. [CrossRef] 
51. Nachon, F.; Ehret-Sabatier, L.; Loew, D.; Colas, C.; Van Dorsselaer, A.; Goeldner, M. Trp82 and Tyr332 are involved in two quaternary ammonium binding domains of human butyrylcholinesterase as revealed by photo affinity labeling with [3H]DDF. Biochemistry 1998, 37, 10507-10513. [CrossRef]

52. Berman, H.M.; Westbrook, J.; Feng, Z.; Gilliland, G.; Bhat, T.N.; Weissig, H.; Shindyalov, I.N.; Bourne, P.E. The Protein Data Bank. Nucleic Acids Res. 2000, 28, 235-242. [CrossRef]

53. Morris, G.M.; Ruth, H.; Lindstrom, W.; Sanner, M.F.; Belew, R.K.; Goodsell, D.S.; Olson, A.J. Software news and updates AutoDock4 and AutoDockTools4: Automated docking with selective receptor flexibility. J. Comput. Chem. 2009, 30, $2785-2791$. [CrossRef]

54. Silman, I.; Harel, M.; Axelsen, P.; Raves, M.; Sussman, J.L. Three-dimensional structures of acetylcholinesterase and of its complexes with anticholinesterase agents. In Biochemical Society Transactions; Portland Press Ltd.: London, UK, 1994; Volume 22, pp. 745-749.

55. Sussman, J.L.; Harel, M.; Frolow, F.; Oefner, C.; Goldman, A.; Toker, L.; Silman, I. Atomic structure of acetylcholinesterase from Torpedo californica: A prototypic acetylcholine-binding protein. Science 1991, 253, 872-879. [CrossRef] [PubMed]

56. Nicolet, Y.; Lockridge, O.; Masson, P.; Fontecilla-Camps, J.C.; Nachon, F. Crystal Structure of Human Butyrylcholinesterase and of Its Complexes with Substrate and Products. J. Biol. Chem. 2003, 278, 41141-41147. [CrossRef] [PubMed]

57. Tallini, L.R.; Bastida, J.; Cortes, N.; Osorio, E.H.; Theoduloz, C.; Schmeda-Hirschmann, G. Cholinesterase inhibition activity, alkaloid profiling and molecular docking of chilean rhodophiala (Amaryllidaceae). Molecules 2018, 23, 1532. [CrossRef] [PubMed]

58. Thomsen, R.; Christensen, M.H. MolDock: A new technique for high-accuracy molecular docking. J. Med. Chem. 2006, 49, 3315-3321. [CrossRef] [PubMed]

59. PyMOL I pymol.org. Available online: https:/ / pymol.org/2/ (accessed on 6 July 2021).

60. Kovarik, Z.; Radić, Z.; Berman, H.A.; Simeon-Rudolf, V.; Reiner, E.; Taylor, P. Acetylcholinesterase active centre and gorge conformations analysed by combinatorial mutations and enantiomeric phosphonates. Biochem. J. 2003, 373, 33-40. [CrossRef] [PubMed]

61. Chatonnet, A.; Lockridge, O. Comparison of butyrylcholinesterase and acetylcholinesterase. Biochem. J. 1989, 260, 625-634. [CrossRef]

62. Howes, M.-J.R.; Perry, N.S.L.; Houghton, P.J. Plants with traditional uses and activities, relevant to the management of Alzheimer's disease and other cognitive disorders. Phyther. Res. 2003, 17, 1-18. [CrossRef] 